Brazilian Legal Culture in the XIX Century: the Role of the Council of State (Division of Affairs of Justice)

\title{
Consultas da Seção de Justiça do Conselho de Estado (1842-1889). A formação da cultura jurídica brasileira*
}

\section{José Reinaldo de Lima Lopes} Professor no Departamento de Filosofia e Teoria Geral do Direito da Universidade de São Paulo e professor na Escola de Direito de São Paulo da Fundação Getúlio Vargas.
Este projeto contou com o apoio da Fundação de Amparo à Pesquisa do Estado de São Paulo - Fapesp, na modalidade auxilio-pesquisa. A catalogação das fontes no banco de dados bem como a revisão dos originais no Arquivo Nacional e a organização dos dados biográficos dos conselheiros contou com a colaboração de André Javier Payar, bolsista pesquisador júnior da Direito-GV (SP). A revisão dos originais no Arquivo Nacional e a discussão de vários pontos da pesquisa contou com a ajuda de Paulo Macedo Garcia Neto, que em sua própria pesquisa de iniciação científica sobre o judiciário do Império veio a tomar conhecimento de algumas decisões do Conselho de Estado aqui referidas e informalmente discutidas entre nós.

\begin{abstract}
Resumo
0 texto levanta a atividade da Seção de Justiça do Conselho de Estado, supondo que ali se desenvolveu uma parcela importante do debate jurídico do Brasil Império. Pela Seção passavam pedidos, recursos e conflitos de jurisdição que exigiam uma resposta legal formal. Também por ali passavam questões de política judiciária e mais geral de política constitucional. Os membros da Seção de Justiça eram muitas vezes juristas reconhecidos e desempenharam um papel importante na formação das estruturas do direito brasileiro. Catalogadas as decisões em um banco de dados, é possivel desenhar um perfil da atividade do Conselho, para posterior análise qualitativa das decisões.
\end{abstract}

\begin{abstract}
This survey of the activities of the Justice Division of the State Council supposes that an important part of the legal debates of 19th Century Brazil took place within that Council. The Justice Division was in charge of petitions, appeals and jurisdictional conflicts which required a formally and legally reasoned decision. It was also responsible for decisions of judicial policies and general constitutional policies. In the 19th century, many of the members of that Division were important legal thinkers who greatly contributed to structural building of Brazilian law. The decisions have been ranked into a data-base from which one can draw a general profile of the Council's activities and further proceed to a qualitative analysis of its decisions.
\end{abstract}

\section{Palavras-chave}

Estado / formas de governo, práticas políticas, judiciário, liberalismo, idéias políticas, Conselho de Estado

\section{Keywords}

State / forms of government, political practices, judicial system, liberalism, political ideas, State Council 
CARVAlHO, José Murilo de. Pontos e bordados: escritos de história e política. Belo Horizonte: Editora UFMG, 1999. p. 224.
Esta investigação nasceu de algumas inquietações com a história do direito brasileiro, particularmente com uma pergunta que se poderia formular da seguinte maneira: onde estava a produção jurídica brasileira no século $X I X$ ? Quais as suas caracteristicas principais? Qual era o traço marcante do pensamento legal do Brasil independente oitocentista?

0 texto a seguir divide-se em 5 seções. Na primeira (1) sugiro que a cultura jurídica brasileira do século XIX encontra-se desenvolvida em parte na atividade do Conselho de Estado, que foi sobretudo um conselho de jurisconsultos. Na segunda (2) parte apresento a idéia de que o Conselho foi órgão institucionalmente importante na decisão de conflitos entre poderes, ainda que de caráter meramente consultivo. Na terceira seção (3) apresento sumariamente o que houve no século XIX na experiência constitucional comparada inclusive constituindo sistemas de contencioso administrativo. Em quarto lugar (4) exponho brevemente o estado das fontes publicadas e manuscritas que até o momento encontrei sobre o conselho, e em seguida, na quinta parte (5) indico brevemente como funcionavam as seções onde realmente se tratava dos assuntos mais cotidianos da máquina de governo, e em seguida analiso mais detidamente os assuntos que chegavam à seção de justiça.

\section{Um debate sobre a cultura jurídica do Brasil oitocentista}

Desde muito cedo aparecem críticas à formação e cultura dos juristas brasileiros. Bernardo Pereira de Vasconcelos, em 10 de julho de 1834, comentando a falta de importância que no Império se dava à educação, dizia: "(...) e depois de proclamada a Independência o que nós temos feito por aumentar nossa civilização, e quais são as grandes providências que se têm dado? Estabeleceu-se dois cursos jurídicos que na verdade estão muito mal montados, que talvez seria melhor, no estado em que se acham, que não existissem."1

Uma afirmação corrente entre alguns dos autores mais importantes do Segundo Reinado insistia na inexistência de uma jurisprudência nacional e, conseqüentemente, na inexistência de orientação dos tribunais. Essa orientação chamava-se ainda normalmente de doutrina, visto que pela análise do caso concreto o tribunal ou autoridade fixava um entendimento da regra geral. Nabuco de Araújo e Cândido Mendes de Almeida, durante os debates sobre a reforma judiciária de 1871 expressavam exatamente essa idéia de ausência de jurisprudência. 0 Supremo Tribunal de Justiça nos seus 43 anos de existência, diziam ambos de formas um pouco diferente, fora incapaz de fixar a doutrina nacional ou a jurisprudência orientadora. Exatamente na mesma linha ia Lafayette Pereira. E como primeira curiosidade convém lembrar que tanto Nabuco quanto Lafayette foram conselheiros de Estado e ambos serviram na seção de justiça do Conselho.

Já em 1843, na sessão de $1^{\circ}$ de julho como deputado geral, Nabuco de Araújo apresentara projeto para reformar o Supremo Tribunal de Justiça, justamente porque, a seu ver, o sistema de recursos implantado até então impedia que se tivesse uma jurisprudência. A jurisprudência tornara-se impossivel "porque o tribunal que é o primeiro na hierarquia, e cujas decisões deviam ter autoridade, decide de um modo, e as relações podem decidir de outro e contrariá-lo. Ora, ninguém desconhece - acrescenta Nabuco - a necessidade de uma jurisprudência no meio das controvérsias a que dá lugar a legislação. Os juizes que examinam o feito para conceder a revista estão 
2

NABUCO, Joaquim. Um estadista do Império. $5^{a}$ ed. Rio de Janeiro: Topbooks, 1997. p. 869.

Os veementes pronunciamentos de Candido Mendes de Almeida fazem-se a esse respeito sobretudo na sessão de 30 de junho de 1871. Seus adversários eram Zacarias de Góes e Vasconcelos e Nabuco de Araújo, que tinham por modelo o parlamentarismo e não o sistema norte-americano. Só nos Estados Unidos, insistia Candido Mendes, o Poder Judiciário tinha cumprido totalmente sua vocação, pois era um aperfeiçoamento da experiência inglesa. Ver: ALMEIDA, Candido Mendes. Senador Cândido Mendes- Discursos parlamentares. 1871-1873. (Org. Aurélio Wander Bastos). Brasilia: Senado Federal, 1982. p.91ss.

PEREIRA, Lafayette Rodrigues. Direitos de familia. 2a. tiragem. Rio de Janeiro: Typ Tribuna Liberal, 1889. p. xv

5

PEREIRA, Lafayette Rodrigues. Direito das cousas. $2^{\text {a }}$. ed. Rio de Janeiro: Jacintho R. dos Santos livreiro, (sdp). p. ix. certamente habilitados para reparar a injustiça e nulidade que acharam, o trabalho é o mesmo. 0 espírito de imitação nos fez transplantar lá da França esta forma de julgamento defeituosa e contra a qual se alevantam os clamores e as vozes de muitos jurisconsultos dessa nação." Como se sabe, o Supremo Tribunal de Justiça examinava os feitos na forma de recurso de revista. 0 recurso, previsto na Constituição do Império art. 164, herdado das Ordenações Filipinas, fora admitido para que o Tribunal revisse os casos sob a alegação de nulidade manifesta (descumprimento de regras que garantissem o contraditório ou a ordem do juízo como então se dizia), ou injustiça notória (ou o descumprimento ou aplicação equivocada da lei material). Uma vez concedida a revista - isto é, reconhecida a nulidade ou o erro do julgamento - o Supremo não tomava ele mesmo a decisão, mas remetia o processo a uma das Relações do Império. Esta não estava obrigada a seguir o entendimento do Supremo e cada uma delas (quatro relações até 1874, doze a partir de então) decidia como bem entendesse.

Nabuco queixava-se outra vez do mesmo tema, durante a discussão da reforma judiciária de 1871, da "anomalia que consiste em poderem os tribunais revisores decidir, em matéria de direito, o contrário do que decide o Supremo Tribunal de Justiça, invertida assim a hierarquia judiciária, e provindo dai a incoerência da jurisprudência, a incerteza dos direitos dos cidadãos e a fraqueza do império da lei, aplicada por modo vário e contraditório. Essa anomalia cessará desde que o Supremo Tribunal conhecer definitivamente da nulidade do processo e da nulidade da sentença; obrigada a Relação revisora a conformar-se com o Supremo Tribunal de Justiça sobre o ponto de direito por ele julgado."2

0 senador Cândido Mendes nos seus diversos pronunciamentos sobre a reforma judiciária de 1871 enfatizava que "temos magistrados, mas não temos Poder Judiciário", um poder anulado diante dos outros, que deveria ter sido o guarda da Constituição, a exemplo do que era nos Estados Unidos, mas que, ao copiar o modelo francês nossa lei fundamental havia desprezado. ${ }^{3}$ Ora, no modelo francês, criticado por Cândido Mendes, implicava que o Tribunal não poderia interferir na interpretação geral da lei (matéria do legislativo), nem em declaração de sua inconstitucionalidade. 0 modelo também tinha semelhanças - mas não identidade - com o sistema brasileiro porque em França havia o recurso de cassação.

Alguns anos mais tarde, já no final do Império, Lafayette Rodrigues Pereira dizia: "O Supremo Tribunal de Justiça, como se acha constituído, é impotente para fixar a inteligência prática das leis. Falta-Ihe a faculdade de cassação: as suas decisões, mesmo do ponto de vista da doturina, podem ser anuladas pelas Relações revisoras. Daí essa variedade e contradições perpétuas nos julgados de nossos tribunais"4. Lamentação repetida em outros termos no seu Direito das cousas: "Jurisprudência brasileira, podese dizer sem temeridade, ainda não a temos. A coleção dos julgados dos nossos tribunais não oferece consistência para formação de uma jurisprudência. Caracteriza-os a mais assombrosa variedade na inteligência e na aplicação do direito. Não exprimem tendência alguma, nem o predomínio do rigor científico, nem o afrouxamento da eqüidade prática."5

Esses três personagens, de grande cultura jurídica e simultaneamente de grande influência política reconhecem o mesmo mal. A cultura jurídica dos três não pode ser colocada em dúvida. Nabuco (1813-1878) era reconhecido a tal ponto que foi encarregado de redigir o projeto de código civil imediatamente após a impossibilidade de Teixeira de Freitas. Teve também 
VENÂNCIO FILHO, Alberto. Das Arcadas ao bacharelismo. 2a. ed. São Paulo: Perspectiva, 1982; ADORNO, Sérgio. Os aprendizes do poder. Rio de Janeiro: Paz e Terra, 1988. p. 145 -150, p.236.

ADORNO, Sérgio. Op. Cit., p. 236.

VENÂNCIO FILHO, Alberto. Op. Cit.,p. 116. intensa atividade legislativa como diretor do Ministério da Justiça e mais tarde como ministro. Foi ele o encarregado da regulamentação do código comercial, e de sua pena saiu o Regulamento dos Tribunais de Comércio. Cândido Mendes de Almeida (1818-1871) foi consultor do Ministério da Justiça e seus pareceres encontram-se em diversas manifestações da seção de justiça do Conselho de Estado, tendo deixado pelo menos três obras de grande repercussão na vida jurídica brasileira: uma versão atualizada das Ordenações Filipinas (1870), uma versão atualizada e acrescida de anexos do Tratado de Direito Mercantil do Visconde de Cairu (1874) e uma compilação organizada das fontes do direito público eclesiástico brasileiro (1866). Lafayette Rodrigues Pereira (1834-1917) continua conhecido até hoje pelos seus dois tratados de direito civil (direito das coisas e direito das pessoas).

Estudiosos recentes, como Alberto Venâncio Filho e Sérgio Adorno em outra perspectiva também dão conta da debilidade, se quisermos, da produção jurídico-intelectual do Brasil independente, especialmente do Brasil pré-18706. Reconhecem, porém, como não poderia deixar de ser, que os bacharéis desempenharam um papel fundamental na politica brasileira, ou, se quisermos, na construção de um Estado nacional. Nesses termos, sugerem que a produção brasileira foi essencialmente política, não propriamente dogmática ou técnico-jurídica. Os dois autores parecem indicar uma espécie de contradição: de um lado, dizem, a produção intelectual dos juristas brasileiros seria pequena, de menor relevância; de outro lado, o Estado imperial foi constituído essencialmente por bacharéis, ou seja os operadores da cultura jurídica tiveram uma importância prática muito grande.

Na opinião de Adorno a academia de São Paulo não foi capaz de "constituir um efetivo quadro de juristas", mas foi "celeiro do mandarinato imperial de bacharéis".7 Venâncio Filho chama de 'desalentador' o quadro do ensino jurídico, informando que "a atividade magisterial era para poucos deles uma atividade importante,e, terminado o concurso para lente substituto a maioria deles se voltava para as atividades da política, da magistratura ou da advocacia."8 Creio que se deve entender tais afirmativas com o grão de sal necessário, de modo a procurar-se a cultura jurídica justamente onde ela foi feita, ou seja na prática cotidiana do aparelho de Estado e nos costumes locais, nas working rules de grupos determinados (como os comerciantes, banqueiros, comissários de café, famílias).

A crítica feita pelos dois autores parece pressupor que o jurista de que falam é o jurista acadêmico, dedicado em tempo integral ou dedicado majoritariamente ao ensino e à pesquisa do direito. Em poucas palavras, parece que o jurista ideal que têm em mente é o professor da nova universidade alemã, o pensador acadêmico. Ora, essa imagem não parece totalmente adequada se levarmos em conta algumas características do direito e de seu ensino em outras partes do mundo à mesma época, ou seja, talvez não seja conveniente estabelecer a crítica do modelo brasileiro a partir de um modelo - a academia alemã - que ainda não é o único ou mesmo o hegemônico sequer no âmbito do direito continental. A título de comparação, a vida dos juristas do século XIX, mesmo em França, é ainda uma vida híbrida: parte do tempo dedicam-se à academia, parte do tempo são chamados a exercer funções de governo ou de legislação e parte do tempo gastam na advocacia (Dupin [1783-1865], Cormenin [1788-1868] etc). Alguns dos mais mencionados, como é o caso de Dalloz (1795-1869) em França, não são mesmo acadêmicos no sentido contemporâneo, mas profissionais que se dedicam a tarefas práticas, como a edição de revistas e coletâneas de deci- 
sões judiciais. Outros transitam de um lado para outro da vida jurídica, ora como professores, ora como legisladores ou homens de Estado. Finalmente, é bom lembrar que na maior parte do século XIX não se exige nos Estados Unidos, ou mesmo na Inglaterra, um curso acadêmico universitário específico para o exercício da advocacia, de modo que as escolas que formam os juristas são escolas profissionais ou técnicas, antes que colégios ou faculdades superiores integradas à universidade.

Certo, a vida acadêmica no Brasil era passageira tanto para os alunos quanto para os professores. Como o magistério era uma função pública entre muitas, visto que o modelo de escola superior era o napoleônico, isto é, como uma carreira de Estado, o cargo de lente para os professores poderia bem ser um cargo como outro qualquer, não havendo no Brasil oitocentista nenhuma tradição prévia de vida universitária. Assim, os professores da academia de São Paulo e Olinda transitavam da escola para a administração da província e vice-versa. Mas será que isto realmente impediu o surgimento de uma cultura jurídica (uma alta cultura, se quisermos)?

A meu juizo isto não foi obstáculo a que houvesse, fora dos estritos muros da academia, um pensamento jurídico, nem que dentro da academia se produzisse alguma coisa. Convivemos tradicionalmente com juristas fora de posições de cátedra há muito tempo no Brasil (e fora do Brasil): Rui Barbosa não foi professor, nem Pimenta Bueno, Uruguai, Teixeira de Freitas, ou Nabuco de Araújo; não o foi tampouco décadas depois João Mangabeira. Foram, porém, juristas e deixaram seu traço.

Essas duas constatações - a dos oitocentistas, dizendo que faltava uma orientação geral à prática brasileira, debitando-a a mecanismos institucionais deficientes, e a novecentista, debitando-a à falta de uma cultura jurídica independente da política - podem ser consideradas tanto complementares quanto antagônicas. Complementares se entendermos que as duas compartem a idéia de que algo falta no pensamento jurídico brasileiro; antagônicas se levarmos em consideração que a primeira não vê a falta de cultura, mas a falta de orientação pelas instituições, enquanto a segunda sugere a falta mesma de uma alta cultura jurídica. As afirmações a respeito de nossa incipiente cultura jurídica sugerem uma questão: como pôde haver um Estado de bacharéis sem que houvesse uma grande cultura jurídica? 0 bacharelismo não é, por certo, garantia de cultura, ou de alta cultura juridica. Pode-se, porém, fazer legitimamente a pergunta sobre a inexistência mesma de uma cultura jurídica, quando o Império foi, por assim dizer, um resultado de burocratas e burocratas juristas?

Algumas investigações que conduzi anteriormente indicaram-me que seria preciso matizar os dois pontos de vista e tentar compreender melhor o que se passava em dois niveis diferentes. 0 primeiro nivel de análise diz respeito às tarefas em que se envolviam os juristas, majoritariamente tarefas práticas. 0 aparente paradoxo (falta de cultura / criação do Estado) poderia ser resolvido, a meu ver, dando-nos conta em primeiro lugar do caráter instituidor que a cultura jurídica brasileira teve no século XIX. Com isto quero dizer que ela teve um viés essencialmente prático e não é de espantar que os juristas fossem pois homens de ação antes que doutrinadores à moda da academia européia (particularmente alemã). Havia duas tarefas simultânea e igualmente importantes. Uma era a de constituir um estado nacional e, por implicação, um direito nacional o quanto possível autônomo do direito português e do direito colonial, aquele direito em que as capitanias eram nada mais que divisões do território para efeito de 
COSTA, Wilma Peres. Do domínio à nação: os impasses da fiscalidade no processo de independência. In: JANCSÓ, István (org.) Brasil: formação do Estado e da Nação. São Paulo: Fapesp/Hucitec/Unijui, 2003. p. 150-51. administração de um domínio ${ }^{9}$. A outra era a de erguer um estado constitucional liberal no qual formas antigas de representação e participação política, como o velho municipalismo das câmaras, fossem substituídas pelo novo ideário do Estado-nação, organizado segundo os princípios constitucionais. Assim, a tarefa que na Europa era de reforma e modernização, no Brasil era quase de invenção. Ainda que, claro está, o novo direito brasileiro se visse na contingência de viver do velho direito colonial ou metropolitano. Os juristas estiveram, portanto, ocupados com essa tarefa imediata e todos os juristas estiveram nela envolvidos de forma bastante absorvente, seja como legisladores, presidentes de províncias, ministros, ou seja como magistrados ou 'oficiais' de justiça e fazenda pelo menos.

No segundo nivel (quanto ao local de produção cultural), seria necessário suspeitar que não havendo uma orientação do Supremo Tribunal de Justiça, nem produção acadêmica consolidada, de algum outro lugar essa orientação deveria proceder, pois bem ou mal o Império conseguiu estabelecer-se e fazer funcionar um sistema de direito público e um sistema de direito privado. Antes que negar a existência de uma cultura jurídica, seria preciso determinar seu sentido e seu local de produção. Sendo ela prática, antes que acadêmica, e não procedendo das faculdades - de onde os lentes era continuamente afastados para exercer funções de Estado - nem do Supremo Tribunal de Justiça, onde encontrá-la?

Ao problema da natureza e profundidade de nossa ciência jurídica, suspeito que se pode compreender e explicar olhando para a espécie de produção cultural dos juristas, que dividirei claramente em dois modelos - ou mesmo dois gêneros literários, cujo papel foi bastante diferente. 0 primeiro modelo-gênero é o dos manuais ou compêndios para uso nas faculdades do Império. Ele não foi particularmente forte, seja pelo número de obras produzidas, seja pelo seu teor, especialmente entre 1827 e 1850. Os compêndios, como se sabe, eram uma prática da universidade de Coimbra, pela qual se submetiam os professores a controle e direção estatal e política. Nas faculdades do Império precisavam da aprovação do governo, que ouvia a Assembléia Geral. Os professores que os produziam estavam inseridos em um sistema napoleônico de universidade, no qual os cargos que ocupavam eram cargos públicos, empregos de Estado. Nos primeiros anos da independência adotavam-se, na falta de compêndios preparados pelos professores, bibliografia estrangeira: ou a portuguesa pré-liberal, como as Instituições de direito português de Mello Freire, ou liberal, como a de Ferreira Borges, ou ainda obras jusnaturalistas e liberais francesas sobretudo, mas eventualmente algumas alemãs e inglesas, conforme a disciplina. Só a partir da década de 1850 é que os manuais se nacionalizaram completamente e passaram a ser produzidos de forma regular, encontrando relativo sucesso de público. Ribas em São Paulo, Pereira Rego e Loureiro no Recife são alguns exemplos.

0 segundo modelo-gênero de produção que não pode ser desprezado é o dos manuais práticos: os manuais para tabeliães e a própria Consolidação das leis civis de Teixeira de Freitas, entre outros. Também aqui a produção cresceu a partir da segunda metade do século XIX. Essa produção prática não deve ser desprezada do ponto de vista intelectual. Primeiro porque corresponde muitas vezes ao esforço de atualidade dos juristas e bacharéis brasileiros, como muito exemplarmente se vê na Consolidação de Teixeira de Freitas. A obra do jurista baiano trazia uma longuíssima introdução de caráter exclusivamente teórico, na qual justificava o verda- 
deiro sistema que havia adotado para colocar em ordem e hierarquizar a legislação civil vigente no Brasil. Essa consolidação não foi transformada em código civil, todos sabemos, mas foi amplamente utilizada como vade mecum em todo País. Basta ver que teve sua publicação aprovada pelo governo imperial e foi reeditada três vezes até o advento do Código Civil em 1917. De outro lado, a prática processual também foi atualizada por meio de obras que 'adaptavam ao foro brasileiro' textos produzidos no exterior, especialmente em Portugal. Nesse caso importa ressaltar que o que é hoje conhecido como 'processo civil' não havia adquirido em parte alguma o estatuto de 'ciência' ou 'disciplina teórica' autônoma, e as publicações nacionais tinham o propósito prático, mas relevante, de pôr a funcionar a máquina da justiça no Império. 0 catálogo da casa publicadora Eduardo e Henrique Laemmert do Rio de Janeiro de 1874 continha 108 publicações brasileiras na área do direito, a maioria de manuais práticos, mas também incluía uma revista jurídica (Revista Jurídica, de doutrina e jurisprudência), além de traduções de autores estrangeiros (o Tratado da prova de Mittermeier, por exemplo), ensaios sobre o casamento civil, uma história do direito romano, o curso de direito civil de Ribas e outros variados títulos.

Esse segundo modelo tampouco pode ser desprezado pois é indicativo, a meu ver, do papel relevante que teve a cultura jurídica e particularmente essa forma de cultura jurídica no Império. Talvez os juristas do Império não estivessem tão preocupados com a 'cientificidade' do direito, quanto com sua 'operabilidade'. Eram construtores de um Estado, não construtores de uma academia. 0 direito era percebido como um saber disciplinado, claro, mas um saber diretamente voltado à operação da máquina social, ou mais precisamente da máquina estatal. Quando Oliveira Vianna criticou os políticos da Primeira República por seu 'bacharelismo' e elogiou a 'elite' imperial é bem possivel que estivesse pensando nessa diferença marcante (homens de ação $x$ cientistas) que se acentuara no direito brasileiro a partir do final do século XIX.

Uma parte da alta cultura jurídica manifestou-se, a meu ver, no Conselho de Estado como órgão auxiliar do Poder Moderador quando de sua interferência na interpretação das leis para sua aplicação, para esclarecimento de dúvidas dos magistrados, para correção mesmo dos magistrados que erravam ou agiam de má fé.

2. 0 Conselho de Estado, conselho de juristas, conselho constitucional. Olhando para o segundo modelo de produção, o dos manuais e obras prática é que me dei conta de uma importante orientação juridica realizada pelos avisos ministeriais. Esses avisos resultavam inúmeras vezes de consultas do Conselho de Estado. Suspeitei, portanto que se Nabuco, Mendes de Almeida e Lafaiete estavam certos quanto à quase irrelevância do Supremo Tribunal de Justiça na formação da cultura jurídica nacional, seria errôneo compreender suas queixas como simples constatação da inexistência dessa cultura. Era ela, no fundo, produzida, faut de mieux como eles pensavam, por eles mesmos e pelos seus imediatos antecessores no Conselho de Estado.

Ao voltar-me para os estudos mais recentes produzidos sobre 0 Conselho de Estado constatei que eles se haviam concentrado no Pleno como órgão de política, ou mesmo como órgão de governo. De fato, a extensa obra de José Honório Rodrigues que organizou e publicou na década de 1970 as atas do Conselho, concentrou-se nas do Conselho Pleno, 
As atas foram publicadas pelo Senado Federal entre 1973 e 1978, precedidas do clássico estudo Conselho de Estado, o quinto poder.

11

0 debate sobre o Poder Moderador continuou sendo vigoroso sobretudo no entre-guerras (1919-1939) na medida da crise das democracias liberais em processo de transformação. Vale a pena fazer menção apenas como exemplo da obra de Carl Schmitt, Der Hütter der Verfassung (O defensor da constituição) de 1931 em que está colocada justamente a questão de algum órgão ou poder com capacidade política e imparcialidade eleitoral para arbitrar conflitos constitucionais. 0 capitulo III começa com uma significativa nota a respeito do poder moderador do Império do Brasil, referindo-se à teoria e à prática que haviam sustentado por aqui o poder neutro. Schmitt chama a atenção para o fato de o poder moderador, explicitamente adotado no Brasil e e em Portugal, ser de fato uma instituição típica em todas as constituições burguesas liberais do século XIX, encarnado num "repertório de prerrogativas e poderes do chefe de Estado (monarca ou presidente do Estado)". SCHMITT, Carl. Il custode della costituzione. Milano: Giuffré, 1981. p.204-205. que se encontram hoje microfilmadas no Arquivo Nacional. ${ }^{10} 0$ Pleno, sem dúvida, era em princípio órgão da grande ou da alta política imperial. Mas não era de lá que procediam principalmente os Avisos ministeriais. Eles nasciam das consultas das seções (Justiça e Estrangeiros, Guerra, Fazenda, Império). Seria interessante, portanto, investigar essas consultas, origem dos famosos avisos. Estes funcionavam como verdadeiras interpretações autênticas dos regulamentos gerais e pareciam ter, pois, força geral. Embora não fossem redigidos na forma de articulados normativos, eram dados a conhecer de modo público e muitas vezes parecem-se com circulares.

Suspeitei também que havia no Conselho de Estado algo ambíguo e que não se poderia compreender sem compreender melhor o que havia sido o Poder Moderador como poder propriamente dito. Muitos discursos sobre o Moderador entre os juristas ficaram presos ao debate conforme colocado nacionalmente, isto é, dentro do Brasil e, pois, enviesado pela política dos partidos e, sobretudo, pela visão republicana contemporânea da divisão de poderes.

Faria mais sentido colocá-lo no seu tempo e não apenas em confronto com a teoria de Benjamin Constant, senão também com relação a outras práticas e experiências. A mais óbvia pareceu-me a norte-americana, tomando como linha de interpretação as palavras de Tocqueville sobre o papel dos magistrados, dos advogados e especialmente da Suprema Corte norte-americana. Tocqueville indicava em suas notas sobre A democracia na América que seria esse ramo judiciário a desempenhar um papel aristocrático e, portanto, conservador na grande política americana. Essa afirmação de Tocqueville era confirmada pelas palavras dos próprios constituintes norte-americanos, que na defesa de um Judiciário federal usavam como argumentos idéias semelhantes às de Constant. 0 Judiciário norteamericano corresponderia, na forma defendida por Hamilton, a um 'poder neutro', sem 'espada e sem bolsa'. ${ }^{11}$

Essa neutralidade, tão buscada pelos liberais do século XIX dava ao Poder Moderador brasileiro a especial característica de interferir em todos os outros poderes para resolver potenciais impasses ou conflitos. Olhada dessa perspectiva, entende-se melhor a atividade do Conselho de Estado, mesmo a do terceiro Conselho de Estado (o de 1841). Se bem que ele não pudesse ser recriado com a mesma justificativa de 1823, uma vez que a reforma constitucional de 1834 o havia abolido naqueles moldes, nota-se que sua atividade indicava a busca de neutralidade. Ora, a neutralidade em determinadas questões, ou para ser mais preciso, a imparcialidade no exame de determinadas questões, é tipicamente atribuição de um juiz, um magistrado. 0 Conselho de Estado consultava o Imperador quando este, ou um ministro de Estado, tivesse que arbitrar conflitos segundo regras. Nesses termos, o Conselho de fato opinava nos casos cotidianos em que o Moderador devesse ser exercido, e não apenas nas aparentemente grandes questões - como a dissolução da Assembléia. Opinava naquelas que envolviam, por exemplo, a separação das esferas administrativa e judiciária em inumeráveis casos; também interferia nos casos em que os poderes locais, isto é, as Assembléias Provinciais, invadiam os poderes da Assembléia Geral. Dai a tarefa de o Conselho rever anualmente a legislação provincial, para mantêla dentro dos limites constitucionais de sua esfera de competência.

Uma análise um pouco mais detida do ponto de vista jurídico indicava ainda uma outra vertente de investigação a ser feita. Pelo regulamento o Conselho operava em seções distintas e a dos negócios da justiça ocupava 
12

Koerner relata um dos casos em que a despeito da contrariedade da política governamental, não houve interferência no julgamento. Esta, aliás, é a atitude comum e corriqueira no Conselho de Estado: sua reserva com relação aos casos submetidos à justiça. Nota-se que há realmente grande autonomia de julgamento. Como o acesso à carreira era controlado pelo governo, via Ministério da Justiça, é claro que havia uma possivel tentativa de 'orientação' do poder judiciário. No entanto, o que também se nota nos muitos casos é que os juizes envolvem-se freqüentemente na política de esfera local (municipal ou provincial) e dai resultam inúmeros conflitos. 0 Conselho muitas vezes deve manifestar-se sobre tais conflitos, e ai sim o quadro das incompatibilidades e das suspensões pode ser revelador de quem está alinhado a quem. KOERNER, Andrei. Judiciário e cidadania na constituição da república brasileira. São Paulo: DCP-USP/Hucitec, 1998. p.67-75. papel especial, tanto porque organizava a máquina judiciária como porque opinava na legislação geral (de direito público e privado, como matéria civil e mercantil). Também aqui não se poderia compreendê-lo sem um olhar mais universal. A montagem de um judiciário nos estados constitucionais do século XIX é feita sob um esquema bem menos claro que o nosso. Em França o judiciário não é propriamente um poder, mas um departamento especializado. Se bem que o juízes tenham garantias próprias, a máquina judiciária é de responsabilidade do governo, do ministro da Justiça que para isso existe especialmente. Nos Estados Unidos o desenho institucional dá mais autonomia ao judiciary department: mesmo assim, a nomeação e o afastamento dos juízes não é assunto interno dos magistrados, passando pelos dois outros ramos.

0 Brasil imperial não era, pois, um caso completamente discrepante de submissão judicial. ${ }^{12}$ Havia um mecanismo, objeto de largos debates, que distinguia os diversos sistemas no mundo, qual seja, a existência ou não da carreira da magistratura e sua configuração nos lugares onde existia. Nos Estados Unidos o sistema de carreira nunca foi implantado. Nesse ponto seguimos a tradição francesa. A carreira aqui, porém, não era exclusiva, passando o magistrado (juiz municipal ou juiz de direito) para cargos legislativos e para cargos executivos (como o de Chefe de Polícia ou Presidente de Província) ao longo de sua vida sem ter que renunciar à magistratura. 0 sistema de incompatibilidades era frágil, e pela Seção de Justiça passavam todas as questões concernentes à organização da carreira (provimento, promoção, remoção, suspensão, afastamento, incompatibilidade, suspeição e responsabilidade de juízes). A máquina judiciária administrava-se ouvindo a Seção de Justiça nos casos dificeis ou duvidosos.

Deve-se lembrar também que em não poucos lugares os juízes municipais e os juizes de direito eram as autoridades civis exclusivas no território, já que as Câmaras municipais haviam sido convertidas em 1828 em órgãos meramente administrativos, ou seja, sem autoridade, representação política ou funções judiciais. Esses juízes viam-se, portanto, diante da necessidade de aplicar a lei em diversos casos como se fossem autoridades administrativas, nomeando os jurados (para compor os júris de pronúncia e sentença), os oficiais de justiça em geral (tanto os oficiais do foro - escrivães, quanto os oficiais de notas - tabeliães, muito embora de modo geral tais ofícios existissem anexados uns aos outros) quando não o fazia o Presidente da Província, e presidindo eleições. Com o Ato Adicional de 1834 e a respectiva lei de interpretação não eram poucos os casos de dúvidas quanto às distinções entre assuntos de competência geral (do governo ou do legislativo) e de competência local (provincial). 0 Ato havia determinado em seus artigos 10 a 12 a esfera de autonomia local. Mesmo assim, havia a obrigação imposta ao Presidente da Província de enviar anualmente todos os atos legislativos provinciais (art. 20 do Ato Adicional) para serem examinados pelo governo e pela Assembléia Geral quanto a sua conformidade com a Constituição. Na esfera do governo esse exame passava pelo Conselho de Estado, nas suas respectivas seções conforme o objeto da legislação.

Além disso, mudanças na legislação (reforma do Código Criminal em 1841, leis especiais, como a lei penal de 1835 sobre escravos e a própria lei Eusébio de Queirós de 1850) exigiram durante muito tempo a solução de conflitos de interpretação.

Dada a necessidade de regulamentação das leis por decretos do governo, era comum também que os juizes consultassem o governo, via 
Joaquim Nabuco narra como seu pai propôs que o governo pudesse interpretar a lei enquanto o Supremo Tribunal de Justiça não assumisse a tarefa (uma vez reformado o sistema recursal da revista). A prática de ouvir o Conselho sobre a interpretação da lei, porém, já vinha desde 1842 como constatei na leitura das consultas. NABUCO, Joaquim. Um estadista do Império. $5^{\text {a }}$ ed. Rio de Janeiro: Topbooks, 1997. p.263-268.

\section{4}

0 caso procedia da Província do Pará e opunha o Presidente da Província ao Cônego Antônio Feliciano de Souza. Lei provincial havia autorizado subvenções financeiras a quem organizasse colégios, o que o cônego fez. 0 presidente da província primeiro concedeu e depois retirou a subvenção, o que levou o cônego a processar judicialmente a província. 0 caso estava já na pauta da Relação de São Luis, quando o presidente da província suscitou o conflito. Nabuco, em voto dissidente, começou a partir daí a afirmar a incompatibilidade do contencioso com a Constituição Imperial (art. 179, § 12). A maioria (Jaguari e Niterói) entendeu que o contencioso existia perfeitamente e que no caso o conflito procedia, pois se tratava de matéria administrativa. A decisão da maioria foi respeitada pelo Imperador. Vale a pena lembrar que esta primeira manifestação de Nabuco (nas consultas impressas) é posterior à lei francesa de 24 de maio de 1872 que havia reorganizado o Conselho francês, separando com nitidez e dando garantias específicas à jurisdição administrativa, enquanto estabelecia um Tribunal de Conflitos, acima do Conselho de Estado e do Tribunal de Cassação, para decidir os conflitos entre jurisdição administrativa e jurisdição judiciária. presidente de província, para esclarecer a aplicação do direito. Sob esse pretexto chegavam ao Conselho muitas consultas..$^{13}$ Como se verá a seguir, pela Seção de Justiça passaram cento e oitenta e cinco (185) consultas vindas de juizes ou outros membros do judiciário, e cento e noventa e duas consultas (192) vindas de Presidentes de províncias e outros administradores, num total de trezentas e setenta e sete (377) consultas, equivalentes a 34\% das questões vindas à Seção. Em resumo, um terço da atividade do Conselho provinha dessa função, dentro da qual se inseria a de exame constitucional dos atos provinciais e dos regulamentos das leis (ver adiante item 5.2).

Tudo isso processou-se pelo Conselho de Estado, antes que pelos tribunais judiciários (Relações e Supremo), em parte pelo já mencionado defeito de sistema que muitos reconheceram mas não conseguiram mudar, e em parte pelo desenho constitucional típico do século XIX que buscava, naquela altura, um árbitro neutro entre os três poderes reconhecidos de modo geral pelas constituições.

0 Conselho de Estado foi considerado órgão consultivo, já que não deliberava propriamente. É no entanto questionável se isto realmente foi ou deveria ter sido assim, tendo em vista tanto a legislação brasileira quanto o direito comparado. De fato, houve pelo menos duas leis que deram ao Conselho funções deliberativas: Lei Eusébio de Queirós, (Lei 581, de 4/9/1850) quanto à matéria de presas especialmente de tráfico de escravos africanos, e a lei no. 563 de 1850 (e o respectivo decreto no. 2.343 de 1859) sobre o Tribunal do Tesouro. A primeira dizia em seu artigo $8^{\circ}$. que todos os apresamentos de navios e a liberdade dos escravos apreendidos seriam julgados em primeira instância pela Auditoria de Marinha, e em segunda instância pelo Conselho de Estado. Suscitou-se então a dúvida, se o Conselho (e sua seção de justiça) seria considerado órgão de decisão, como a lei deixava entender. Alguns juristas entenderam que 0 Conselho neste caso deliberava e não apenas aconselhava o Imperador. 0 Conselho mesmo pode examinar sua capacidade e definir-se diante da lei. Na consulta de 28 de outubro de 1850 a Seção de Justiça manifestouse pelo entendimento de que mesmo no caso da Lei Eusébio de Queirós a manifestação do Conselho era simplesmente opinativa/consultiva. 0 assunto foi então remetido ao Pleno, que em 14 de novembro de 1850 confirmou que o Conselho não era "convertido em tribunal" pelo fato de opinar na confirmação das sentenças do almirantado quanto às presas de navios negreiros. 0 Imperador conformou-se com a opinião, como o fazia na maioria dos casos.

Quando a discussão sobre a existência do contencioso administrativo intensificou-se, a partir de um primeiro voto explícito de Nabuco a respeito da constitucionalidade dos poderes dos presidentes de provincia suspenderem provisoriamente 0 andamento de causas judiciais (na consulta de 5 de setembro de 1872) ${ }^{14}$, o Conselho teve a oportunidade de reafirmar sua doutrina: mesmo nos casos de conflito de jurisdição, apenas opinava, pois a decisão, a seu juizo era de quem detinha o Poder Moderador, ou seja, o imperador mesmo na função de poder neutro, que afinal, resolvia a disputa entre os dois poderes.

Como dito antes, o Conselho pareceu inclinar-se à idéia de que era apenas consultivo. Naturalmente isto pode ser tributado ao fato de os juristas, mesmo os conservadores que serviam no Conselho, serem obrigados a reconhecer que não eram um dos poderes constitucionais e que o Ato Adicional de 1834 o havia retirado do número de órgãos do Estado 
15

Foram decididas 880 consultas. Restam 222 consultas não resolvidas ou cuja resolução não foi encontrada pelos editores das coleções, como eles mesmos advertem. Não foi possivel realmente localizá-las no Arquivo Nacional, pois a resolução era dada pelo Imperador ao lado mesmo do pedido. Quando não está no pedido, os livros de registro também não a mencionam e não mencionam o paradeiro da consulta. mencionados na constituição. Tinham consciência de que o conselho era criação legal, não constitucional, de modo que formalmente deveriam restringir suas atribuições. Apesar disto vale notar que no seu funcionamento efetivo o Imperador confirmou 84\% das opiniões (741 consultas) da Seção de Justiça expressas por unanimidade ou por maioria. Remeteu apenas 2,2\% delas (20 consultas) a uma segunda opinião no Conselho Pleno, e decidiu a questão a favor de votos/opiniões minoritárias em 3,9\% dos casos ( 35 consultas). 15

Aparentemente o contencioso administrativo estava definido no Decreto no. 124 de 5/2/1842 (art. 24 a 41). Mas já vimos que também havia um contencioso organizado no Tesouro Nacional, um contencioso da Lei Eusébio de Queirós, e houve em 1857 uma disciplina do Recurso à Coroa (Decreto 1.191, de 28/3/1857) que atribui competência exclusiva ao Conselho de Estado para conhecê-lo (art. 30).

Embora se possa falar que o Conselho de Estado era onde desaguava o contencioso administrativo brasileiro, a questão era polêmica entres os contemporâneos. 0 Visconde do Uruguai não estava nada satisfeito com os modos do Conselho a esse respeito. Segundo ele, o contencioso brasileiro estava restrito aos casos do Tesouro, pois a lei no. 563 de 1850 e o decreto no. 2.343 de 1859 haviam tentado organizar o contencioso no âmbito da fazenda simplesmente. "A base, dizia ele, que o nosso contencioso administrativo de Fazenda e das outras repartições tem em legislação diretamente emanada do corpo legislativo é insignificantíssima. 0 contencioso administrativo que temos resulta, senão todo, quase todo de regulamentos do governo, feitos em virtude de autorizações do corpo legislativo, o qual nem sequer deu para isso as bases convenientes." Tirante o Tesouro, nos outros ministérios o contencioso era "um verdadeiro caos, no qual ainda não penetrou um só raio de luz." Mais ainda, denunciava que os ministros deixavam de ouvir o Conselho, reinava a indistinção entre o gracioso e o contencioso e disso resultava que "nossa Administração é absoluta."

A partir da década de 70 o Conselheiro Nabuco de Araújo insistiu diversas vezes na inexistência do contencioso administrativo, pelo menos na forma como fora regulado no Brasil. Para ele, atribuir-se ao Presidente de Província o poder de sustar o andamento de um feito judicial implicava violação da separação de poderes. Encontram-se diversos votos seus divergindo de seus pares, já que a maioria manteve posição favorável á existência do contencioso administrativo. Em certas ocasiões, observada a natureza do caso, o Imperador contrariou a maioria, apoiando a posição de Nabuco (é o que acontece na Resolução imperial de 4 de dezembro de 1875, arbitrando o conflito a favor da Câmara de Porto Alegre).

\section{Experiências comparadas}

A experiência mais marcante no âmbito europeu de início do século XIX foi a francesa, com todas suas marchas e contra-marchas. A constituição napoleônica e a carta da monarquia restaurada mantiveram em funcionamento um Conselho de Estado que aos poucos firmou-se como instância relevante na vida jurídica e política. Essa foi sem dúvida a fórmula de equilibrio que sobreviveu. 0 Conselho francês nascera da Constituição de 13 de dezembro de 1799 (art. 52): "Sob a direção dos cônsules, um Conselho de Estado é encarregado de redigir os projetos de lei e os regulamentos da administração pública e de resolver as dificuldades surgidas em matéria administrativa." Para garantir a autonomia dos poderes constitucionais, o 
16

ROYER, Jean-Pierre. Histoire de la justice en France. 3a ed. Paris: PUF, 2001. p.591.

17

MANNORI, Luca; SORDI, Bernardo. Storia del diritto amministrativo. Roma/Bari: Laterza, 2003. p.330-31

18

Os termos são praticamente os mesmos pelos quais se atribuiu poder jurisdicional ao Tribunal do Tesouro no Brasil em 1859 e se determina o Recurso à Coroa em 1857. MANNORI, Luca; SORDI, Bernardo. Op. Cit., p. 337

19

STOLLEIS, Michael. Geschichte des öffentlichen Rechts in Deutschland. V.2. München: Verlag C. H. Beck, 1992. p.117 art. 75 dizia: "Os agentes do governo, que não os ministros, não podem ser processados por fatos relativos a suas funções senão por decisão do Conselho de Estado no caso; o processo terá lugar nos tribunais ordinários." No regulamento de 26 de dezembro de 1799, o art. 10 deu ao Conselho poderes de interpretação das leis (alínea 11): "0 Conselho de Estado explicita o sentido das leis, sob consulta (renvoi) feita pelos cônsules das questões que lhes sejam presentes. Ele se pronuncia, em tais consultas: 1 - sobre os conflitos que possam surgir entre a administração e os tribunais; 2 - sobre os casos contenciosos cuja decisão tenha sido enviada anteriormente aos ministros." Está aí o modelo de grande sucesso. Não mencionado na Carta de 1814, sobreviveu de fato e foi regulamentado em diversas ordens e decretos e dura com diversas reformas até hoje.

Sua reforma mais importante deu-se em 1872 (Lei de 24 de maio) quando o Conselho de Estado deixa de ser um órgão do poder real - exercendo a jutiça retida ou reservada (justice retenue) do próprio rei - e passa a ser um órgão autônomo, que exerce uma justiça delegada (justice delegue) ou seja, que the é dada propriamente. Ele é considerado uma jurisdição independente, dentro da ordem administrativa com dupla competência: para deliberar em última instância nos casos de contencioso administrativo e para decidir os casos de abuso de poder de qualquer autoridade administrativa ${ }^{16}$. A mesma lei de 1872 , porém, cria ou re-cria o Tribunal de Conflitos, que decide o conflito de jurisdição entre a ordem administrativa (cujo órgão de cúpula seria o Conselho de Estado) e a ordem judiciária (cujo órgão de cúpula seria o Tribunal de Cassação).

A restauração francesa deu, a meu ver, o ambiente em que o constitucionalismo brasileiro se afirmou e desenvolveu, e nele a idéia de Benjamin Constant foi marcante, como solução possível à instabilidade plebiscitária que um modelo mais exclusivamente majoritário e democrático parecia provocar.

Em seguida podem-se mencionar os casos italiano e alemão. A Itália unificada houve-se também com a questão de um organismo minimamente isento para julgar o governo, não de forma propriamente política mas de modo jurídico. Em primeiro lugar pensou-se no Conselho de Estado, nos mesmos moldes do sistema francês. Mas em 1865, a lei de 20 de março definiu que as questões de direito seriam decididas pelos tribunais ordinários. Segundo Mannori e Sordi o contencioso administrativo foi "rejeitado (...) como 'máscara de justiça' e 'instrumento de despotismo'", sendo que em 1889 veio a ser criada finalmente uma Quarta Seção no Conselho de Estado17. A ela foram atribuidos os "recursos em casos de incompetência, excesso de poder e violação de lei por atos e providências administrativas".18

0 século XIX na Alemanha foi também o século da justiça administrativa em particular. A progressiva definição de um Estado de direito (Rechtsstaat) fez-se com a procedimentalização da justiça administrativa. Não se submetendo aos tribunais comuns, a administração e burocracia públicas foram limitadas por regras a Ihes impor fórmulas e procedimentos controlados por tribunais administrativos. Stolleis afirma que o tema da justiça era um tema central na medida mesma em que a pergunta por quem julgará ("quis judicabit") era decisiva para a unificação da sociedade burguesa ${ }^{19}$. E, no entanto, a existência de uma justiça administrativa só se afirmou na Alemanha no último terço do século XIX como solução de compromisso entre o controle judicial completo dos atos administrativos 
20

STOLLEIS, Michael. Geschichte des öffentlichen Rechts in Deutschland. V.2. München: Verlag C. H. Beck, 1992. p.241-42.

21

Ibidem, p.243.

22

DIRCEY, A. V. Introduction to the study of the law of the constitution. [1885]. $9^{2}$ ed. London: MacMillan \& Co, 1950. p.330.

23

Deve-se destacar que não faltam nos Estados Unidos tribunais administrativos propriamente ditos, funcionando ao lado de agências administrativas (autarquias) tais como o serviço de seguridade social, a própria Comissão de Comércio e outros mais. Suas relações com os tribunais ordinários é definida em cada caso.

\section{4}

A expressão de J. Camilo de 0. Torres é a seguinte: "Exerceu o Conselho de Estado uma função análoga, posto que mais ampla, à da Suprema Corte dos Estados Unidos. Coube-Ihe, como o tribunal americano (que tantos brasileiros admiravam, esquecidos de que possuiam algo semelhante ou melhor dentro de casa) duas tarefas básicas - o estabelecer o império da le e fixar o principio da supremacia do governo geral e locais. Coube ao Conselho de Estado, além destas, a missão de assegurar a continuidade da administração e do governo." TORRES João Camilo de Oliveira. 0 Conselho de Estado. Revista dos Tribunais. São Paulo, 1965. p.122-23. pela justiça comum ou ordinária, e a manutenção do sistema anterior pelo qual a administração mesma decidia da legalidade de seus atos. 200 compromisso consistiu em estabelecer tribunais de competência, procedimento e regras exclusivas para o julgamento dos atos administrativos que afetassem direitos dos cidadãos. 0 compromisso foi apoiado por conservadores e por um pequeno grupo de liberais influenciados pelo sistema francês. Com isto, finalmente, tornou-se possivel, segundo Otto Mayer, criar-se propriamente uma "ciência" do direito administrativo21. Até hoje sobrevive ali uma justiça administrativa, sob o império do Superior Tribunal Administrativo (Verwaltungsgerichtshof).

Do lado da tradição anglófona, tanto a Inglaterra quanto os Estados Unidos judicializaram desde sempre as questões administrativas. Dicey dizia mesmo que o fato de os funcionários do governo não se subordinarem aos tribunais ordinários na França era o sinal mais evidente de que ali não havia rule of law como concebido na Inglaterra. Na linguagem de Dicey ou existe rule of law ou droit administratif.22 Na sua leitura o que o direito administrativo e seu outro lado, o contencioso administrativo, fazem é dizer que os "empregados públicos [agentes do governo] quando agem bona fide no exercicio de seus deveres oficiais" precisam de "ser protegidos do controle dos juízos ordinários", o que não se dá na Inglaterra porque ali o agente do executivo obteve, em caso de necessidade excepcional, uma autorização excepcional do próprio Parlamento, ou seja, uma lei.23

Deve-se destacar, porém, que de certa maneira algumas das funções que na França ficaram a cargo do Conselho de Estado ou do poder real (expressão consagrada na Carta de 1814 e nas palavras de Benjamin Constant) nos Estados Unidos foram outorgadas à Suprema Corte. Assim, a Suprema Corte constitui-se em um órgão de verdadeira moderação, pois interpreta em última instância as leis e a própria constituição, e por isso mesmo dispõe de uma espécie de poder de veto no processo legislativo. Além disso, é constituída por juizes vitalícios (como os membros do Conselho de Estado), que não procedem da carreira de magistratura. Ela não é o final de uma carreira burocrática mas claramente um órgão de alta política, razão pela qual seus membros não são selecionados por concurso ou por eleição direta: são nomeados com o concurso do presidente da república (que, como se sabe, é eleito indiretamente) e do senado federal (órgão pensado como conservador, por seus mandatos mais longos do que os da câmara de deputados e seus requisitos de idade). Finalmente, o modelo norte-americano encontrou nos Papéis federalistas uma justificativa para a Suprema Corte interferir no processo legislativo. No artigo no. 78, Hamilton afirmava mesmo que ela seria o bastião contra o abuso de poder do legislativo, e a vitaliciedade dos cargos na corte cumpriam este papel de torná-la, neste aspecto, mais forte do que o próprio corpo legislativo.

Assim, não é de surpreender que no constitucionalismo oitocentista em toda parte se pensasse em um órgão capaz de opor-se às maiorias episódicas do legislativo eleito. 0 Conselho de Estado no Brasil parece responder, com a precariedade de sua organização não obstante, a esse mesmo intento.

É possível pensar que o Conselho exercia em muitos termos e casos função análoga à da Suprema Corte norte-americana. A analogia já foi feita antes e não é despropositada ${ }^{24}$. Creio mesmo que a Suprema Corte terminou sendo nos Estados Unidos uma espécie de poder neutro. Sua jurisdição originária (decidindo os conflitos federativos, por exemplo) e 
Conselheiros que serviram na Seção de Justiça ou participaram de sessões conjuntas onde se examinaram matérias originalmente atribuidas à Justiça. sua jurisdição recursal (interpretando em última instância a constituição federal) são típicas de um árbitro jurídico-político. 0 fato de seus membros não deverem sua indicação ao voto popular, de serem mantidos nos seus cargos pro vita, e de sua nomeação depender de um ato jurídico complexo (um verdadeiro processo) em que o executivo faz a indicação e o legislativo a confirma, torna sua configuração muito semelhante à de um poder de arbitragem última como o da Suprema Corte estadunidense. Não por acaso, Tocqueville observava no seu A democracia na América que as grandes questões politicas americanas terminavam sempre na Suprema Corte - isto é, buscavam finalmente um enquadramento jurídico - e mais importante talvez, via na magistratura uma nova aristocracia que - justamente por não ter que recorrer ao voto popular e viver dentro de uma espécie de estamento profissional de gosto e hábitos próprios - desempenhava um papel conservador nos embates democráticos. Uma leitura dos debates constitucionais norte-americanos e sobretudo da defesa da Constituição de 1787 feita pelos Federalistas indica a meu ver que esse papel conservador não era um sub-produto indesejado, mas parte integrante do que se buscava com os juizes federais não eleitos.

Nesses termos, o Conselho de Estado brasileiro sem dúvida tem alguns traços de grande semelhança com a Suprema Corte. Os conselheiros eram indicados pro vita, sua atribuição (legal, e não constitucional, como gostavam de lembrar seus opositores) dava-Ihe poderes de examinar (se não de decidir, como visto acima) os conflitos entre os poderes (executivo e judiciário) e de distribuir entre os três poderes algumas tarefas. Neste último sentido refiro-me ao fato de o Conselho tomar conhecimento de casos concretos e resolver se era o caso de mandar (1) o assunto ao legislativo (para legislar ou para emitir leis interpretativas ou declaratórias), (2)de mandar o assunto para o executivo (se fosse hipótese de elaborar regulamento ou interpretar regulamento ou decreto), ou (3) de devolver o caso ao judiciário para simples aplicação da lei.

Outro traço de semelhança estava na espécie de fiscalização que fazia do processo legislativo. Essa fiscalização dava-se de duas maneiras. Em primeiro lugar quanto à legislação geral (isto é nacional), o Conselho pronunciava-se previamente examinando os projetos (de lei e de regulamento). Em segundo lugar quanto à legislação provincial o conselho funcionava examinando posteriormente e ano a ano a legislação das províncias para verificar se estavam conforme a suas atribuições constitucionais (isto é, conforme ao Ato Adicional de 1834). Claramente sua função de guardião da constituição pode dar-lhe um ar de poder neutro ou poder constitucional como o da Suprema Corte americana.

Mas as semelhanças, ainda que muitas, não podem levar à identificação. Uma primeira diferença bastante marcante está no fato de os conselheiros poderem servir simultaneamente em outro poder, o legislativo, e poderem afastar-se, sem perder a posição no Conselho, para servir no executivo. Em outras palavras, não havia um regime de incompatibilidades que isolasse os conselheiros de outras funções de Estado. No legislativo os conselheiros eram em geral senadores e podiam acumular funções; no executivo vários exerceram funções de ministros, presidentes do conselho de ministros, e presidentes de província (casos em que se afastavam do Conselho). A tabela 1 a seguir ${ }^{25}$ mostra os conselheiros que serviram na seção de justiça e as funções que exerceram nos outros poderes. 
Tabela 1

Conselheiros de Estado que participaram da Seção de Justiça (ou sessões conjuntas) e exerceram outras funções de Estado

\begin{tabular}{|c|c|c|c|c|c|}
\hline & 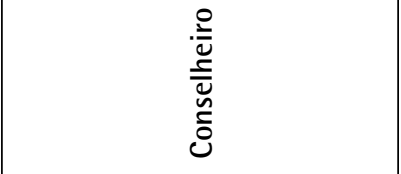 & 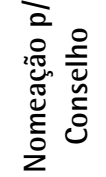 & $\begin{array}{l}\frac{1}{0} \\
\frac{0}{0} \\
\frac{c}{\nu} \\
\sim\end{array}$ & 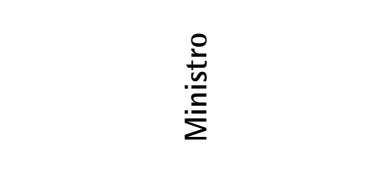 & 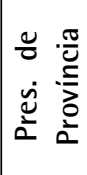 \\
\hline 1 & Bernardo P. Vasconcelos & 1842 & Sim & $\begin{array}{l}\text { Sim (Fazenda, Justiça e } \\
\text { Império) }\end{array}$ & Sim \\
\hline 2 & Lopes Gama (V. Maranquape) & 1842 & Sim & Sim (Estrangeiros e Justiça) & Sim \\
\hline 3 & Bispo de Anemuria & 1842 & - & - & - \\
\hline 4 & Carneiro Leão (V. Paraná) & 1842 & Sim & $\begin{array}{l}\text { Sim (Fazenda, Estrangeiros e } \\
\text { Justiça) }\end{array}$ & Sim \\
\hline 5 & Silva Maia & 1842 & Sim & Sim (Fazenda e Justiça) & Sim \\
\hline 6 & $\begin{array}{l}\text { José da C. Carvalho (M. de } \\
\text { Monte Alegre) }\end{array}$ & 1842 & Sim & Sim (Império) & - \\
\hline 7 & $\begin{array}{l}\text { Miguel Calmon Du Pin e } \\
\text { Almeida (V. Abrantes) }\end{array}$ & 1843 & Sim & Sim (Fazenda e Estrangeiros) & - \\
\hline 8 & Limpo de Abreu (V. Abaeté) & 1848 & Sim & $\begin{array}{l}\text { Sim (Fazenda, Estrangeiros, } \\
\text { Justiça, Império e Marinha) }\end{array}$ & $\operatorname{Sim}$ \\
\hline 9 & $\begin{array}{l}\text { Cândido José de A. Viana (M. } \\
\text { Sapucai) }\end{array}$ & 1850 & Sim & $\begin{array}{l}\text { Sim (Fazenda, Justiça e } \\
\text { Império) }\end{array}$ & $\operatorname{Sim}$ \\
\hline 10 & Montesuma (V. Jequitinhonha) & 1850 & Sim & Sim (Estrangeiros e Justiça) & - \\
\hline 11 & $\begin{array}{l}\text { Joaquim J. Rodrigues (V. } \\
\text { Itaborai) }\end{array}$ & 1853 & Sim & $\begin{array}{l}\text { Sim (Fazenda, Império, } \\
\text { Marinha e Guerra) }\end{array}$ & Sim \\
\hline 12 & Paulino José (V. Uruguai) & 1853 & Sim & Sim Estrangeiros e Justiça) & Sim \\
\hline 13 & Eusébio & 1855 & Sim & Sim (Justiça) & - \\
\hline 14 & P. Bueno (M. São Vicente) & 1859 & Sim & Sim (Estrangeiros e Justiça) & Sim \\
\hline 15 & Domiciano & 1866 & - & Sim (Agricultura) & Sim \\
\hline 16 & $\begin{array}{l}\text { Francisco Salles Torres Homem } \\
\text { (V. Inhomirim) }\end{array}$ & 1866 & Sim & Sim (Fazenda) & - \\
\hline 17 & Nabuco & 1866 & Sim & Sim (Justiça) & Sim \\
\hline 18 & $\begin{array}{l}\text { Manoel Vieira Tosta (M. } \\
\text { Muritiba) }\end{array}$ & 1866 & Sim & $\begin{array}{l}\text { Sim (Justiça, Marinha e } \\
\text { Guerra) }\end{array}$ & $\operatorname{Sim}$ \\
\hline 19 & $\begin{array}{l}\text { Luiz P. Couto Ferraz (V. Bom } \\
\text { Retiro) }\end{array}$ & 1867 & $\operatorname{Sim}$ & - & Sim \\
\hline 20 & $\begin{array}{l}\text { Carlos Carneiro de Campos ( } 3^{\circ} \\
\text { V.de Caravellas) }\end{array}$ & 1870 & Sim & Sim (Fazenda e Estrangeiros) & Sim \\
\hline 21 & Sayão Lobato (V. Niterói) & 1870 & Sim & Sim (Justiça) & - \\
\hline 22 & $\begin{array}{l}\text { José Ildefonso (V. Jaguary e B. } \\
3 \text { Barras) }\end{array}$ & 1870 & $\operatorname{Sim}$ & Sim (Justiça e Império) & Sim \\
\hline 23 & João Lustosa (M. Paranaguá) & 1879 & Sim & $\begin{array}{l}\text { Sim (Fazenda, Estrangeiros, } \\
\text { Justiça, Marinha e Guerra) }\end{array}$ & Sim \\
\hline 24 & José Caetano de Andrade Pinto & 1879 & - & - & \\
\hline 25 & Afonso Celso (V. Ouro Preto) & 1882 & $\operatorname{Sim}$ & Sim (Fazenda e Marinha) & - \\
\hline 26 & $\begin{array}{l}\text { João Lins V. Cansansão e } \\
\text { Sinimbu(V. Sinimbu) }\end{array}$ & 1882 & $\operatorname{Sim}$ & $\begin{array}{l}\text { Sim (Fazenda, Estrangeiros, } \\
\text { Justiça e Agricultura) }\end{array}$ & Sim \\
\hline 27 & Lafayette & 1882 & Sim & Sim (Justiça) & Sim \\
\hline 28 & $\begin{array}{l}\text { Luis Antonio Vieira da Silva } \\
\text { (V.Vieira da Silva) }\end{array}$ & 1882 & $\operatorname{Sim}$ & Sim (Marinha) & Sim \\
\hline 29 & $\begin{array}{l}\text { Nunes Gonçalves (V. e S. Luís } \\
\text { do Maranhão) }\end{array}$ & 1889 & $\operatorname{Sim}$ & - & Sim \\
\hline 30 & $\begin{array}{l}\text { Francisco de Paula Sousa e } \\
\text { Melo }\end{array}$ & 1845 & $\operatorname{Sim}$ & Sim (Fazenda) & \\
\hline 31 & Bernardo Sousa Franco & 1859 & Sim & Sim (Fazenda e Estrangeiros) & Sim \\
\hline 32 & Felizardo Sousa e Melo & 1859 & Sim & Sim (Marinha e Agricultura)) & Sim \\
\hline
\end{tabular}


Por esses cálculos, 43\% dos conselheiros estiveram presentes em casos consultados pela Seção de Justiça.
Como se vê, dos trinta e um conselheiros ${ }^{26}$ que participaram das deliberações da seção de justiça (alguns participaram em sessões conjuntas, quando o assunto interessava a mais de um ministério, outros participaram como substitutos de algum conselheiro afastado justamente para ser ministro) apenas quatro não exerceram ministério algum (Visconde de São Luis, Andrade Pinto, Couto Ferraz e o Bispo de Anemuria). E apenas três não foram senadores (Andrade Pinto, Domiciano e o Bispo de Anemuria). Isto significa, pois, que embora o Conselho pudesse ter funções de 'defensor da constituição', não as tinha com o isolamento que a pouco e pouco se construira no caso dos Estados Unidos. Nem com o mesmo sistema que veio a vingar na França.

Uma segunda diferença era que a Suprema Corte estava definida na Constituição norte-americana, embora sua organização, jurisdição e funcionamento pudessem (como podem até hoje) ser definidos por lei ordinária. Nosso Conselho foi tirado da Constituição em 1834, voltando a existir com estatuto legal, mesmo que, como indicado acima, suas opiniões fossem dadas em assuntos materialmente constitucionais (como a decisão de conflitos de atribuições entre outros poderes constitucionais).

Um terceiro ponto que diferencia nosso Conselho é seu caráter consultivo, como já foi dito, jamais ultrapassado propriamente na mentalidade da época. A Suprema Corte decidia (como até hoje decide) e decidia com caráter vinculante e de precedente obrigatório para todos os juizes e tribunais dos Estados Unidos. 0 Conselho opinava e para dar execução a suas opiniões dependia em primeiro lugar de confirmação do Imperador, em seguida ou de um ato administrativo do Ministro (Aviso, para casos singulares, Decreto ou Regulamento para instruções de caráter geral), de atos da Assembléia Geral ou atividade judicial.

Finalmente pode-se destacar o fato de o Conselho acumular funções consultivas para o exercício de poderes dos ministérios, da Justiça no caso em particular das consultas examinadas neste estudo. Isto significava que na maioria dos casos a consulta dizia respeito a decisões de competência própria do Ministério da Justiça, como divisões de comarcas, conflitos entre pretendentes a ofícios de justiça, correção de regulamentos de leis, disciplina de atividades econômicas e mercantis cujo controle e definição pertenciam às funções administrativas dos tribunais de comércio e assim por diante. Por isso, além de seu caráter consultivo, nota-se em algumas opiniões dos conselheiros em seus votos na seção (não no Pleno) a noção implícita de que eram auxiliares do "governo" no sentido mais restrito de "administração pública".

0 que parece relevante, portanto, para a continuidade da pesquisa a respeito do desempenho da seção de justiça do Conselho de Estado é levar em consideração essa experiência internacional, na qual o Império se inseriu, tratando não tanto o Conselho como órgão do despotismo, ou do poder pessoal apenas, senão como uma experiência possivel entre tantas outras. Em segundo lugar, tentando observar como no âmbito de suas consultas aparece em operação uma parcela importante da cultura jurídica brasileira oitocentista. Ali talvez se encontrem peças faltantes no quebracabeças da história jurídica do País. 


\section{As fontes utilizadas}

\subsection{Fontes impressas}

A fonte primária do estudo consistiu no exame das consultas publicadas. As consultas e pareceres foram publicados em matéria de justiça, fazenda, negócios eclesiásticos, guerra e marinha. Estão disponiveis as seguintes edições das decisões:

- 1884 - Imperiaes resoluções tomadas sobre consultas da secção de justiça do Conselho de Estado, organizada por José Próspero Jeová da Silva Caroatá. É a edição mais completa contendo resoluções desde 1842 até 1883.

- 1877 - Imperiaes resoluções tomadas sobre consultas da seç̧ão de justiça do Conselho de Estado. Foi localizado apenas um primeiro volume que contém resoluções selecionadas. Foram organizadas por Bellarmino Braziliense Pessoa de Mello, empregado então no Ministério da Justiça. Não parece ter havido um segundo volume, pois Caroatá, na abertura de sua coletânea confirma que havia sido tentada a coleção das consultas por Bellarmino, mas não se havia passado de 1846, justamente o último ano constante do referido primeiro volume.

- 1869 - Consultas do Conselho de Estado sobre negócios eclesiásticos. Considerando que até 1860, quando o decreto n. 1.067 transferiu a matéria de direito eclesiástico para o Ministério do Império, as questões relativas a cargos e jurisdição eclesiástica eram administradas pelo Ministério da Justiça, foram também levantadas as decisões constantes nesse volume.

- 1907 - Consultas do extincto Conselho de Estado sobre assumptos da competência do Ministério da Justiça e Negócios Interiores. Rio de Janeiro. (mandada fazer por Tavares Lyra, Ministro da Justiça).

Existem diversas edições de consultas e resoluções da seção de fazenda (organizadas por Emílio Xavier Sobreira de Mello respectivamente em 1867, 1870, 1871,1874,1879, 1884, 1886, 1890), do ministério da guerra (por Manoel Joaquim do Nascimento e Silva, em 1884), do ministério da marinha (por Antônio Carlos César de Mello Andrada, em 1868).

A coleção de Caroatá contém 1042 consultas (resolvidas ou não) e se trata da mais extensa de todas as coleções publicadas para a seção de justiça. Mesmo assim, não reproduz todas as manifestações do Conselho. Algumas encontram-se na coletânea de assunto eclesiásticos (que contém 65 consultas).

\subsection{Fontes manuscritas}

No Arquivo Nacional encontram-se encadernados os originais de quinhentas e trinta e nove consultas (com os respectivos requerimentos e papéis que as instruíram) em quarenta e nove volumes. As consultas ali estão resolvidas pelo Imperador ou constam os avisos respectivos expedidos pelo ministério. Esta coleção contém as consultas resolvidas, encadernadas e separadas. As consultas estão em ordem alfabética, e cada uma em papel almaço tem encartados em si os papéis referentes ao caso (aviso do ministro, designação do relator, pedido, traslados, ofícios dos presidentes de província, etc). 0 imperador assina à esquerda da primeira página, e abaixo dele o ministro da justiça. Abaixo vem a indicação (aviso expedido, ofício expedido, etc com a data). 
27

Pimenta Bueno descrevendo o processo perante o Conselho sugere justamente a organização da secretaria nestes termos: "Convinha determinar que as petições fossem remetidas à secretaria do Conselho de Estado, que convém criar, que a fossem inscritas em um registro na data de seu recebimento, e dentro de dois dias entregues ao respectivo relator, notando-se isso mesmo no registro; e enfim que fossem os negócios, o quanto possivel, relatados pela ordem de sua inscrição, salvo o caso de urgência ou dilações necessárias." Afinal, a secretaria nunca foi criada, ficando a cargo de cada ministério a organização dos papéis de assuntos de sua competência. Um exame superficial nos registros e atas mantidos no Arquivo Nacional mostrou que o Ministério do Império trazia a documentação tratada mais uniformemente ao longo do tempo e seus livros de registro conservam um padrão de inscrição. 0 Visconde do Uruguai queixava-se de que as seções de Justiça e do Império eram sobrecarregadas de trabalho e a ausência de um corpo estável de funcionários burocráticos devia contribuir para uma certa desorganização dos respectivos trabalhos.

\section{8}

São eles, pela ordem do juramento prestado: 1 - João Manuel Pereira da Silva, 2 - Francisco Thomaz Neves, 3 - José Pedro Carlos da Fonseca, 4 - Augusto Teixeira de Freitas, 5 Fernando Sebastião Dantas Mello, 6 - Agostinho Marques Perdigão Malheiro, 7 - Ernesto Ferreira França, 8 - Joaquim Saldanha Marinho, 9 Benvenuto Augusto de Magalhães Taques e 10 - Izidoro Borges Monteiro. Realmente o Decreto 124 havia fixado o número de dez advogados (art. 37)

\section{9}

RODRIGUES, José Honório. Conselho de Estado: o quinto poder? Brasilia: Senado Federal, 1978. p.277-78.
Nem todas elas encontram-se no volume de Caroatá. Algumas inseridas no último volume, por exemplo, em que se discute a construção dos novos fóruns na Corte e nas capitais da Bahia, Pernambuco, São Paulo e Rio Grande do Sul, não se acham nas fontes impressas (nem de Caroatá, feita em 1884, nem de Tavares Lyra, feita em 1907). É possível, porém, que as diferenças se dêem também porque nem todas as consultas entradas ou protocoladas chegassem a ser apreciadas pela Seção ou mesmo chegassem a ser resolvidas.

Os livros de protocolo encontrados no Arquivo Nacional mostram realmente que há muitas consultas não recolhidas nas publicações. Para se ter uma idéia das diferenças, basta dizer que os livros de protocolo apenas para o período de 1870 a 1889 dão conta da entrada de 787 consultas, 0 que por si já equivale quase ao total das consultas recolhidas por Caroatá para o período de 1843 a 1870 (contei 755 consultas)! Caroatá não esclarece os critérios de sua seleção. É possível que o critério seja a maior ou menor complexidade do caso, mas isto não é certo. Há inúmeros pedidos de graça e comutação de pena não incluídos na coletânea, e ao mesmo tempo há vários pedidos de aposentadoria, sem nenhuma aparente complexidade jurídica. Uma possivel explicação para o destaque dado às aposentadorias pode ser a falta de uma legislação geral sobre o assunto, o que gerava decisões sempre ad hoc mas de grande interesse para um grupo de empregados (juizes, desembargadores, servidores dos tribunais e da própria secretaria - ou ministério - da justiça). Assim, colecionar decisões particulares sobre aposentadorias tinha seu interesse na época e o exame continuado das decisões e consultas poderia dar aos interessados alguma noção de critérios (doutrina). Já a concessão de graça (comutação das penas) poderia continuar sem regra mais definida (embora na maioria das vezes o Conselho opinasse pela comutação) e o público beneficiário da graça era seguramente outro (mais vasto e variado). A própria idéia de graça implica a de falta de uma regra geral (o caso é examinado por seus fatos particulares) e, pelo que se viu não eram poucos os casos em que os pedidos de graça diziam respeito a escravos, ou seja, a um público bastante diferente dos servidores da justiça. Assim, na coleção de Caroatá, quando confrontada com as fontes manuscritas, há muito menos exemplos de pedidos de graça do que os que foram encontrados. Quanto a isto só cabe, por enquanto especular.

Nota-se que a forma dos registros da atividade da Seção variou no tempo e o fundo mantido no Arquivo Nacional está cheio de interrupções que podem perfeitamente espelhar a falta de organização da secretaria, objeto da queixa dos contemporâneos. 27 Existe um Livro do juramento dos advogados do Conselho de Estado onde constam os juramentos de dez advogados, entre 9 de maio de 1842 e 25 de abril de 1867. ${ }^{28}$ Mas em outro livro, usado para Assentamento do Ministro e Secretário de Estado e dos Conselheiros de Estado com designação das Secções a que pertencem (Cód. 296, 2 volumes), a fls. 22 constam os nomes de alguns advogados do Conselho (com o respectivo decreto de nomeação para o cargo), incluindo Benevenuto Augusto de Magalhães Taques e Isidro Borges Monteiro que haviam prestado juramento no primeiro livro, e Francisco de Paula de Negreiros Sayão Lobato (decr. 29.9.66), Antônio Pereira Rebouças (29.9.66) e Urbano Sabino Pessoa de Mello (que, registra o livro, não aceitou) que não apareciam no primeiro livro. Assim, pelo livro dos juramentos os advogados são uns, mas pelo assento do Ministério existem outros. José Honório Rodrigues fornece uma lista ainda maior, tomando os dados inclusive das publicações da imprensa do Rio de Janeiro ${ }^{29}$. 
Tabela 2

Advogados do Conselho de Estado

\begin{tabular}{|c|c|c|c|}
\hline 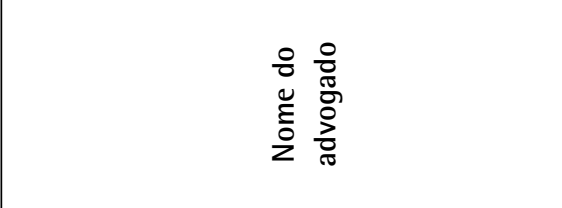 & 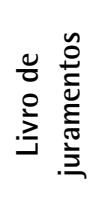 & 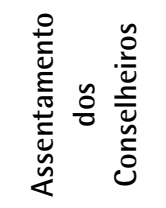 & 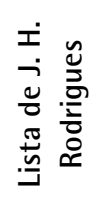 \\
\hline Agostinho Marques de Perdigão Malheiro & Sim & Sim & Sim \\
\hline Antônio Moreira Tavares & $X$ & Sim & Sim \\
\hline Antônio Pereira Rebouças & $x$ & Sim & Sim \\
\hline Augusto Teixeira de Freitas & Sim & Sim & Sim \\
\hline Benvenuto A. Magalhães Taques & Sim & Sim & Sim \\
\hline Caetano Alberto Soares & $X$ & $X$ & Sim \\
\hline Ernesto Ferreira França & Sim & Sim & Sim \\
\hline Fernando Sebastião Dantas Mello & Sim & 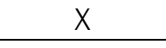 & Sim \\
\hline Francisco de Assis Coelho & $x$ & $x$ & Sim \\
\hline Francisco Thomaz Neves & Sim & $\mathrm{X}$ & Sim \\
\hline Franciso de Paula de Negreiros Sayão Lobato & $\mathrm{X}$ & Sim & Sim \\
\hline Izidoro Borges Monteiro & Sim & Sim & Sim \\
\hline João Batista Pereira & $x$ & Sim & Sim \\
\hline João Manuel Pereira da Silva & Sim & Sim & Sim \\
\hline Joaquim Gaspar de Almeida & $X$ & $X$ & Sim \\
\hline Joaquim Saldanha Marinho & Sim & Sim & Sim \\
\hline José Pedro Carlos da Fonseca & Sim & $\mathrm{X}$ & Sim \\
\hline Manuel Inácio Gonzaga & $x$ & Sim & Sim \\
\hline Urbano Sabino Pessoa de Mello & $x$ & Não aceitou & Sim \\
\hline
\end{tabular}

Tabela 2- fontes: Livro do juramento dos advogados do Conselho de Estado (Arquivo Nacional), Assentamento do Ministro e Secretário de Estado e dos Conselheiros de Estado (Arquivo Naciona), José H. Rodrigues (Conselho de Estado - o quinto poder, p. 277-278)

Outros livros anotam o protocolo (entrada das consultas no Ministério, com respectiva remessa à Seção, designação de relator e decisão), mas não parecem ter continuidade, pois os registros se interrompem no meio do livro, ou são feitos em diferentes livros com diferentes critérios de anotação (às vezes são anotados os nomes das partes, às vezes o nome da província de onde procede o negócio). Há ainda diversos livros de atas, mas também freqüentemente sem continuidade cronológica.

\section{A seção em funcionamento}

\subsection{As seções em geral}

0 regulamento do Conselho foi fixado pelo Decreto no. 124 de 5 de fevereiro de 1842. A Seção de Justiça composta de três conselheiros, como todas as outras seções, era presidida pelo respectivo ministro que, no entanto, não votava, nem mesmo em caso de empate (art. 18). Os pareceres da seção eram resolvidos pelo Imperador, ouvindo ou não o pleno (art. 90). 0 decreto dividia os assuntos em contenciosos e não contenciosos. Os assuntos não contenciosos compreendiam o exame das leis provinciais e todos os negócios encaminhados pelo seu presidente, vale dizer, o ministro da pasta respectiva (art. 21). Os assuntos contenciosos compreendiam: a solução dos conflitos (de competência) entre autoridades administrativas, os conflitos (de jurisdição, hoje ditos de atribuição) entre autoridades judiciárias e administrativas, questões de presas, e processo administrativo em geral (art. 33) no qual eram apreciados os interesses diante ou contra a administração. 
30

A organização mais explícita e formal do contencioso administrativo dava-se com o Tribunal do Tesouro Nacional (Decretos 736 de 1850 e 2.343 de 1859). Por tais decretos o Tribunal do Tesouro decidia conflitos de competência entre empregados da fazenda e recursos vindos das repartições fiscais. 0 Dec. 2.343 de 1859 previa que as decisões do Tribunal do Tesouro teriam "autoridade e a força de sentença dos Tribunais de Justiça" (art. 25) e, no entanto, poderiam ser anuladas pelo Conselho de Estado em caso de incompetência, excesso de poder e violação da lei (art.29). Tais decisões eram encaminhadas, porém, à seção de fazenda do Conselho. Quanto ao contencioso administrativo em geral a disciplina que havia era a do Decreto 124 de 182, artigos 24 a 51. Nabuco era contra o contencioso na forma disposta pelo Decreto 124 pois ali o Presidente da Província, uma autoridade administrativa, podia interromper o processo judicial em curso (embora apenas provisoriamente enquanto não se manifestassem o Conselho e a "Augusta Pessoa").
Embora o Conselho Pleno fosse visto como o órgão de consulta política por excelência, as seções foram as que mais ativamente funcionaram. 0 cotidiano da administração passava, pois, pelas seções. As quatro seções (justiça e estrangeiros, fazenda, guerra e império) vincularam-se inicialmente aos seus respectivos ministérios. Mesmo tendo sido os ministérios reorganizados, criando-se mesmo alguns novos, as seções permaneceram sempre as mesmas. Isto significa que cada uma das seções poderia apreciar os assuntos de mais de uma pasta.

As seções consultavam (emitiam parecer) mediante provocação do respectivo ministro (aviso) ou de algum interessado (recurso ou mesmo pedido administrativo) tanto em matérias contenciosas (recursos), quanto em matérias administrativas (jurisdição graciosa, provocada por representação ou pedido), além de serem diversas vezes provocadas em nome do Imperador a pronunciar-se sobre projetos de lei, de regulamentos, de alterações políticas ou administrativas. Para que o caso chegasse ao Conselho era necessário que fosse processado pela secretaria do Ministério e não foi possivel saber, por enquanto, com que eficiência, precisão e universalidade os pedidos eram encaminhados.

As seções funcionavam como instância consultiva tanto da administração quanto do contencioso administrativo. 0 Decreto 124 dizia que a Resolução Imperial poderia ser tomada com ou sem parecer das seções ou consulta do Conselho (art. 47), e ela é que seria "executada como qualquer sentença judiciária, e pelos mesmos juizes e forma pela qual estas o são" (art. 51). Esta era, aliás, uma das queixas de quem ou era contra a existência do contencioso administrativo, ou o criticava porque não estava adequadamente organizado no Brasil. 30

Visto que o Conselho era composto de 12 membros ordinários, cada uma das seções funcionava com três conselheiros. Ao lado dos doze conselheiros ordinários e dos doze extraordinários, havia dez advogados habilitados a requerer perante o Conselho. Entre eles estiveram alguns dos mais eminentes juristas do Brasil imperial, como Augusto Teixeira de Freitas, Agostinho Perdigão Malheiro e Saldanha Marinho.

\subsection{A Seção de Justiça e os objetos de sua competência}

No caso da seção de justiça é possivel avaliar que funcionava com duas entradas muito diferentes, cada uma procedendo de uma das pastas a que se vinculava (Justiça e Negócios Estrangeiros) tanto assim que há dois arquivos distintos para seus negócios. Um acervo encontra-se no Arquivo Nacional, antiga repartição do Ministério da Justiça; outro encontra-se no Arquivo Histórico do Itamarati, ou seja, no Ministério de Relações Exteriores, antigo ministério dos negócios com estrangeiros. Os livros de registro também são diferentes, havendo uma pluralidade de controles em ambos ministérios.

\subsubsection{Controle de constitucionalidade (opinião sobre projetos de lei, exame da legislação provincial)}

Anualmente examinava a legislação provincial do ano anterior para verificar sua conformidade com a Constituição e com os termos do Ato Adicional (Decreto no. 124, art. 21). 0 principal objeto da consulta, nesses casos, era saber se a Provincia não havia excedido seus poderes legislativos. No caso da seção de justiça, a maioria numérica dos atos legislativos provinciais sobre os quais se pronunciava dizia respeito aos cargos de justiça (à 
31

"Art. 80: Todos os apresamentos de embarcações, de que tratam os artigos primeiro e segundo, assim como a liberdade dos escravos apreendidos no alto mar, ou na costa antes do desembarque, no ato dele, ou imediatamente depois em armazéns e depósitos sitos nas costas e portos, serão processados e julgados em primeira instância pela Auditoria de Marinha, e em segunda pelo Conselho d"Estado. 0 Governo marcará em regulamento a forma do processo em primeira e segunda instância, e poderá criar auditores de marinha nos portos onde convenha, devendo servir de auditores os juizes de direito das respectivas comarcas, que para isso forem designados." criação ou divisão de comarcas, termos, distritos, ofícios de justiça etc). Em resumo, examinava-se o desempenho legislativo da província no âmbito da administração da justiça principalmente. Como a justiça englobava a polícia, as questões envolviam também matéria policial-criminal (segurança pública) e guarda nacional (ordem pública). Caso não estivesse conforme, a seção recomendava ao Governo (isto é, ao ministro respectivo) que encaminhasse a questão à Assembléia Geral que suspenderia a legislação local. Nisto, como se vê, suas funções eram semelhantes a de alguns organismos de controle de constitucionalidade, embora neste caso o controle fosse de legislativos locais (províncias) não do corpo legislativo geral.

0 que era comum também era o exame prévio dos projetos de lei geral, no qual a constitucionalidade da medida era expressa ou implicitamente examinada. Pela seção de justiça passaram diversas reformas importantes, como a dos casamentos (propostas sobre o casamento civil), a das hipotecas e a das reformas judiciárias. Mas também ao responder consultas e dúvidas mais simples os conselheiros apontavam falhas da legislação. A inconstitucionalidade do próprio contencioso administrativo foi diversas vezes levantada por Nabuco.

\subsubsection{Contencioso administrativo e conflitos de competência e jurisdição}

$\mathrm{Na}$ esfera contenciosa, isto é, nos conflitos que poderiam ser resolvidos com força de decisão judicial, a Lei Eusébio de Queirós (Lei n. 581 de 4 de setembro de 1850), sobre o tráfico de escravos, parece que pretendeu transformar o Conselho em verdadeiro tribunal, pois as presas de navios negreiros deveriam ser decididas pela Auditoria de Marinha do caso (que julgava as presas boas ou não) em primeira instância, e obrigatoriamente revistas pelo Conselho (por meio da seção de justiça) para confirmá-las ou não (Lei n. 581/1850, art. 80). ${ }^{31}$ A despeito dos termos da lei, o Conselho considerou-se ainda apenas uma instância consultiva, conforme consulta de outubro de 1850, justamente porque remetia sua opinião ao Imperador para resolvê-la.

Considerava-se também contencioso administrativo o conflito que envolvia direitos de servidores ou oficiais de justiça, membros da guarda nacional e semelhantes. Um caso em que Nabuco de Araújo reconhece haver contencioso administrativo nestes termos é o das sucessoras de um oficial de justiça que havia transferido seu tabelionato para outra pessoa. 0 novo tabelião ficara com o encargo de pagar-Ihes uma pensão, cujo valor fora originalmente arbitrado pelo governo. Nabuco, acompanhado de Jequitinhonha insistiu em que o caso era administrativo, não judicial (Consulta de 16 de julho de 1867).

Conflitos de competência podiam dar-se entre diversas autoridades administrativas. No caso de conflito entre judiciário e administração dizia-se propriamente conflito de jurisdição e o Presidente da Província (ou, na Corte, o Procurador da Coroa), por iniciativa própria ou mediante provocação, suspendia o processo judicial, mandava ouvir os interessados e decidia o conflito (Decreto no. 124, art. 24-26). Se a decisão fosse favorável à administração, teria caráter provisório e subia ao Conselho. Se a decisão fosse favorável ao judiciário não havia necessidade de confirmação pelo Conselho. Essa era uma atribuição específica da Seção de Justiça, já que o conflito com a justiça era de sua esfera de assuntos. Outro conflito possivel era entre autoridade eclesiástica e autoridade secular. Também aí 
a primeira decisão competia aos presidentes de província. Vale lembrar que inicialmente as questões eclesiásticas competiam ao Ministério da Justiça, passando em seguida ao Ministério do Império (como dito acima, em 1860). Quando o conflito se dava entre autoridade civil e autoridade religiosa falava-se de usurpação de jurisdição e também pertencia ao Conselho de Estado (Decreto 1.191 de 1857).

No caso da seção de justiça esse contencioso terminava por definir a própria máquina judiciária, pois a seção estava encarregada de examinar as controvérsias surgidas na distribuição dos cargos, empregos e ofícios de justiça, bem como opinar nos casos de conflitos de competência (isto é, conflitos entre diferentes órgãos do judiciário ou diferentes órgãos da administração) e jurisdição (isto é, conflitos entre governo e justiça). A seção de fazenda era o órgão do contencioso administrativo mais próprio e mais volumoso, pois resolvia pendências entre os cidadãos e o Estado em matéria de tributos, imposições e algumas outras questões relevantes (Decreto 736 de 1850 e 2.343 de 1859).

\subsubsection{Organização judiciária}

Como o Ministério da Justiça era encarregado da administração do aparelho judicário, era perante a seção de justiça que se processavam os pedidos relativos a todos os empregos e ofícios de justiça. Diziam respeito à provisão (concursos, nomeações, remoções, promoções, mas também suspensões e demissões), remuneração e vantagens, e eventualmente a conflitos de competência ou disputas pelo próprio cargo (nos casos dos ofícios há inúmeras consultas sobre rendas devidas por terças partes, heranças, propriedade dos ofícios, indenizações ou queixas pela perda de receita ou renda devida à divisão de comarcas, desanexações de oficios etc). Deve-se destacar que a suspensão dos magistrados era competência do poder moderador (Constituição do Império, art. 101, VII).

Empregos eram os cargos próprios de Estado, remunerados (por vencimentos ou ordenados) pelos cofres públicos (provinciais ou gerais). Nesse âmbito, o dos empregos, encontravam-se as magistraturas (juizes de direito, juizes municipais, desembargadores e ministros do Supremo Tribunal, mas também os chefes e delegados de polícia) e os servidores permanentes das secretarias do ministério e dos tribunais. Os ofícios, no caso da justiça, consistiam especialmente nas escrivanias, tabelionatos e registros, remunerados pelas custas e emolumentos pagos pelas partes (embora também os magistrados pudessem ter parte nesses emolumentos, recolhidos e distribuídos pelo Estado). Na administração da justiça havia ainda questões relativas aos poderes das províncias para organizar os serviços respectivos, bem como o já mencionado exame das leis provinciais (desmembramento de comarcas, termos, distritos, que vinham a ter grande repercussão politica: mudanças dessa natureza implicavam aumentar ou diminuir poderes de juizes vitalícios e, portanto, favorecer interesses políticos específicos).

\subsubsection{Recursos de graça ao Poder Moderador}

Também por ela passavam todos os pedidos de graça (recursos de graça) sobre os quais deveria pronunciar-se o Imperador, já que se tratava de comutar penas aplicadas pela justiça ordinária em primeiro lugar (portanto, interferência do poder moderador sobre o poder judiciário, Constituição do Império, art. 101, VIII). 


\subsubsection{Resolução de dúvidas e interpretação de lei}

Esta lista de atribuições complica-se ligeiramente na seção de justiça porque por ela passaram algumas das questões mais candentes do debate jurídico e político do império por um mecanismo não previsto no regulamento do Conselho: trata-se da resolução de dúvidas surgidas na aplicação da lei. As dúvidas provinham de órgãos do executivo e dos órgãos do judiciário. A prática mostra que se adotou um sistema parecido ao sistema do conflito de jurisdição ou de competência. 0 presidente da província tomava conhecimento da dúvida do juiz, promotor, ou outro oficial de justiça, resolvia-a (provisoriamente) e encaminhava o caso ao Conselho de Estado, que fixava em última instância o entendimento devido. Com o tempo criou-se um verdadeiro hábito de consultas ao Conselho (via presidente de província e ministro da justiça), diversas vezes repreendidos os consulentes por abdicarem de seu poder e dever de interpretar a lei no caso concreto. Foram encontradas 378 consultas em que se pedia a resolução de dúvidas na aplicação da lei ou do regulamento. Destas, 185 procederam de juizes e/ou tribunais judiciários, e 193 vieram de autoridades administrativas. É um número significativo que ocupa um terço de todas as consultas publicadas.

Nota-se que quando se tratava de interpretar regulamentos a seção não se negava a dar sua opinião. Mas o número de recusas de interferir na interpretação da lei era grande quando se tratava de interpretá-la em casos específicos (a seção os remetia ao poder judiciário) ou ao poder legislativo (quando a dúvida era gerada pela deficiência mesma da redação legal ou pela deficiência do sistema legal como um todo, ou seja em casos de reconhecida lacuna ou antinomia).

Por força de tais dúvidas é que se vêem várias questões de direito privado chegarem à seção, inclusive de direito mercantil. Como os tribunais de comércio (criados em 1850) eram também parte da máquina judiciária, questões mercantis chegavam por essas vias transversas à Seção de Justiça. Chegavam também diretamente, porque o Decreto 1.597, de 1855 (Regulamento dos tribunais de comércio) em seu art. $8^{\circ}$ havia criado o recurso para o Conselho de Estado de todas as decisões dos tribunais de comércio relativas a: concessão de moratórias e reabilitação de falidos, proibição ou anulação de registro de contratos de sociedades mercantis, multas, suspensão ou demissão de corretores e outros agentes auxiliares do comércio e multas a administradores de trapiches alfandegados e capitães de navios.

\subsection{Os ramos do direito e os assuntos que passaram pela Seção}

As decisões estão sendo catalogadas segundo grande ramo do direito e assuntos. Os grandes ramos do direito escolhidos foram: a) no direito público: direito constitucional, administrativo, fiscal, processo penal, processo civil, e eclesiástico; b) no direito privado: o direito civil e o mercantil. Os assuntos, depois de uma primeira leitura dos pareceres, foram distribuidos debaixo das seguintes rubricas: aposentadorias, provimento e propriedade (expressão usada em vários pareceres) de cargos ou oficios de justiça, provimento ou propriedade de cargos ou ofícios da administração (inclusive fiscal), provimento ou propriedade de cargos de igreja, contratos, propriedade (inclusive direitos reais de garantia e hipoteca), familia, sucessões, responsabilidade, sociedades, escravidão, indigenas, guarda nacional, jurisdição, júri. Temas como guarda nacional, júri, escravidão, indígenas, foram destacados por sua recorrência. 
Consultas sobre cargos de justiça formaram parte bastante significativa dos temas do Conselho e não é de surpreender, pois vivia-se então o período de constituição dos serviços de justiça e pode-se imaginar que se estava a sair das velhas fórmulas dos ofícios patrimoniais e dos juizes leigos e eletivos para ofícios burocráticos e juizes 'empregados' do Estado como se costumava dizer.

\subsubsection{Consultas entre 1842 e $\mathbf{1 8 5 0}$.}

Boa parte das atividades da seção de justiça concentrava-se na administração da máquina judiciária. No período entre 1842 e 1850 foram localizadas cento e vinte e oito (128) consultas na coletânea de Caroatá. Destas, quarenta e uma (41), ou seja, $32 \%$, diziam respeito a matéria de direito administrativo. Dentre elas, 36 (ou seja $87 \%$ das consultas envolvendo direito administrativo) diziam respeito a cargos de justiça, e dentre elas 22 (ou seja 61\%) consultavam sobre ofícios de justiça (serviços cartorários prestados por cidadãos privados).

0 segundo número mais expressivo de consultas no período (32 consultas, ou seja $\mathbf{2 5 \%}$ ) abrange processo penal. Nesta esfera, o problema mais recorrente diz respeito ao processamento de ações penais: temas como júri, direitos dos indiciados ou acusados, poderes de instrução, respeito ao contraditório, formalidades do processo, e outros semelhantes formam o grande corpo de matérias. É preciso destacar que boa parte das questões surgidas a partir da instalação do Conselho referem-se à lei de reforma do processo penal (3 de dezembro de 1841) que havia abolido o júri de pronúncia, a instrução penal contraditória e os poderes de instrução do juiz de paz.

0 terceiro grupo de questões concentra-se em matérias de direito constitucional (14 consultas, representando 10,93\% do total). As matérias de direito constitucional, na classificação organizada, comportam o exame das leis provinciais bem como os processos de responsabilização de juizes. Classifiquei-as como matéria constitucional visto que o Conselho era ouvido sobre as leis provinciais especialmente para verificar se a Assembléia havia se mantido dentro de seus poderes (conforme o Ato Adicional). Caso a Seção julgasse que a Assembléia ultrapassara seus poderes, sugeria ao Imperador que se levasse o assunto à Assembléia Geral do Império, que poderia revogar a lei. Quanto à imposição das penas aos juizes (remoção, suspensão e responsabilização), tratei o tema como constitucional visto que era uma das hipóteses de interferência de um poder (o Moderador) sobre outro poder (o Judiciário), existindo ai um dos mais claros casos de conflito de poderes constitucionais.

0 quarto grupo de consultas mais freqüentes diz respeito a processo civil, com cerca de 11 pareceres $(8,5 \%)$, seguido de direito penal (7 pareceres, $5,4 \%)$, direito civil (6 pareceres, 4,6\%), direito eclesiástico $(3,1 \%)$ e direito mercantil $(2,3 \%)$.

Esses grupos perfazem 91\% da atividade do Conselho no período, restando uma série de outros temas que, no periodo, não foram materialmente significativos como matéria fiscal (hoje direito tributário) e outros, embora no agregado somem quase $9 \%$ das matérias. As questões fiscais concentravam-se, naturalmente, na seção de fazenda, que era ouvida no processo legislativo, nas iniciativas de reforma e também no contencioso dos contribuintes com o tesouro. 
Em matéria de direito civil foram encontrados 6 casos até 1850. Deles, (I) um caso dizia respeito diretamente ao exercício do direito de propriedade: tratava-se de pedido de autorização para aforar perpetuamente terras de uma capela. 0 Conselho decidiu que não era necessária autorização; esta só era necessária em casos de conversão de bens imóveis em apólices (na forma da lei de 1845). Um segundo (II) parecer sobre direitos reais foi dado como avaliação do projeto de reforma da lei do registro de hipotecas em 1844. 0 Conselho rejeitou a proposta do projeto, por ser infactivel: ao copiar o modelo francês, o projeto ignorava as dificuldades próprias do Brasil, onde não se encontraria gente habilitada a cuidar do registro em cada município, sobretudo porque não haveria remuneração. A sugestão do Conselho foi de criar-se um registro por Província ou comarca. Um terceiro (III) caso situa-se também na zona de fronteira entre o direito de propriedade e o direito de família e sucessões: trata-se de um pedido de autorização (procedente da Corte, em 1847) em que uma viúva quer vender a um dos filhos parte das terras que obteve no inventário do marido. Outros (IV e V) dois casos (1844 e 1845) tratam de direito de família e procederam de consultas dos juizes de órfãos (de Santa Catarina e de São Paulo): no primeiro indagava-se o que fazer com os órfãos desvalidos da comarca, e o no segundo o juiz (comarca de Itu) colocava em dúvida as habilitações de casamento que o vigário fazia dos órfãos de pai, ouvindo apenas as mães. Neste último, o Conselho, contrariando a prática do vigário, impôs a interferência do juiz de órfãos, pois "a mãe, apesar de ter maior amor do que o pai, por ser mulher tem a razão mais débil" e, sendo viúva, não poderia decidir sozinha. Um último (VI) caso (de 1850) é um pedido de interpretação da lei vindo da Bahia, em que o juiz de paz tem dúvidas sobre sua competência para tomar testamentos.

Como se vê, nas primeiras décadas da vida independente, o Conselho é ouvido em matérias de propriedade quando há algum ônus ou vínculo que parece precisar de autorização especial para ser desfeito ou transferido. De outro lado, é também ouvido em casos envolvendo 'incapazes' ou 'quase capazes'. Os outros conflitos, entende-se, eram resolvidos regularmente pelo judiciário. Três casos chegaram por provocação dos juizes, sendo que um deles é levantado em meio a um potencial conflito entre a justiça eclesiástica e a justiça civil (comarca de Itu, autorizações concedidas pelo vigário). Dois outros são pedidos administrativos de autorização para realizar negócios entre particulares (aforamento perpétuo, venda a descendente). Um é resposta a pedido do próprio governo para opinar sobre projeto de lei. Dessa perspectiva, a maioria dos casos procedeu de situações de aplicação concreta e "judicial" das leis civis. Por esses caminhos vê-se como o Conselho poderia bem influir na própria definição do direito privado. As primeiras decisões são todas dadas pelo Conselho sem maior preocupação. Ao longo das décadas nota-se que aos poucos ele procura devolver aos juízes a definição das questões, em diversas vezes com palavras mais ou menos duras contra o hábito de consultar desnecessariamente quando o juiz tem plenamente o poder de jurisdição.

\subsubsection{Consultas entre 1842-1889.}

0 quadro a seguir indica o número de consultas colecionadas por Caroatá e Tavares Lyra e vale para todo o periodo de funcionamento do Conselho (entre as fontes publicadas). 
Tabela 3

Consultas distribuídas por ramos do direito

\begin{tabular}{|l|c|}
\hline \multicolumn{1}{|c|}{ Áreas do direito } & Número de consultas \\
\hline Administrativo & 465 \\
\hline Processo penal & 126 \\
\hline Constitucional & 125 \\
\hline Mercantil & 116 \\
\hline Penal & 109 \\
\hline Processo civil & 66 \\
\hline Civil & 44 \\
\hline Eclesiástico & 27 \\
\hline Outros & 15 \\
\hline Fiscal & 9 \\
\hline Total & 1102 \\
\hline
\end{tabular}

\subsubsection{Assuntos que chegavam ao Conselho}

0 quadro a seguir mostra os números encontrados para o mesmo periodo quanto a alguns assuntos sobre as consultas cuja resolução está registrada nas fontes. Há outros assuntos não mencionados, embora com números também significativos (competência, jurisdição, júri, índios e direitos indígenas etc).

\section{Tabela 4}

Consultas resolvidas distribuidas por assuntos (dentro dos ramos do direito)

\begin{tabular}{|l|c|}
\hline \multicolumn{1}{|c|}{ Assuntos } & Número de consultas \\
\hline Cargos e ofícios de justiça & 358 \\
\hline Jurisdição e competência & 131 \\
\hline Escravidão & 67 \\
\hline Guarda nacional & 52 \\
\hline Aposentadorias & 44 \\
\hline Sociedades & 23 \\
\hline Familia & 16 \\
\hline Penas e pena de morte & 16 \\
\hline Propriedade & 15 \\
\hline Sucessões & 15 \\
\hline Contratos & 12 \\
\hline Diversos (júri, indios, etc) & 131 \\
\hline Total (consultas resolvidas) & 860 \\
\hline
\end{tabular}

Tabela 4 - exclui consultas remetidas ao Pleno (20) e não resolvidas (222)

Esses assuntos (729 casos, excluidos os diversos) compreendem 66,1 $\%$ do trabalho da seção. Os temas de cargo de justiça por si equivalem a $32,4 \%$ de todos os negócios consultados e publicados e a 41,6 \% das questões resolvidas, e o segundo maior grupo continua dentro da esfera da justiça, pois diz respeito a jurisdição e competência e abrange 15,2 \% das consultas que a seção decidiu e o Imperador resolveu. Em terceiro lugar aparece o tema da escravidão (7,7\%). Assuntos relativos à Guarda Nacional chegaram a $6 \%$ dos casos e o total de casos de direito privado (sociedades, contratos, família, propriedade e sucessões) alcançou algo como 9,4\%.

\subsubsection{Como o Conselho era provocado}

É também de interesse notar como os casos chegavam ao Conselho. Este dado pode ser extraído do campo objeto. 
Tabela 5

Consultas distribuidas pelo objeto (forma de provocação)

\begin{tabular}{|l|c|}
\hline \multicolumn{1}{|c|}{ Objeto } & Número de consultas \\
\hline Interpretação (Administração) & 193 \\
\hline Pedido & 189 \\
\hline Interpretação (Judiciário) & 185 \\
\hline Recurso & 159 \\
\hline Conflito de jurisdição & 56 \\
\hline Outros & 320 \\
\hline Total & 1102 \\
\hline
\end{tabular}

Dos assuntos classificados a maior atividade da Seção concentrou-se na resolução de dúvidas apresentadas pelos administradores, fossem eles autoridades localizadas nas províncias, fossem autoridades ou funcionários da Corte. 0 segundo maior número está em pedidos. Classifiquei como pedidos as petições dirigidas diretamente ao Conselho ou eventualmente ao Ministro que as encaminhava diretamente à Seção. São diferentes dos recursos, que se referem a casos em que previamente fora dada uma decisão. Entre os muitos pedidos, um dos mais freqüentes refere-se a aposentadoria, pois não havia no Império uma lei geral sobre o assunto. Podiam também dizer respeito a remuneração de cargo e alguns outros casos em que o interessado julgava-se pessoalmente com um direito ou interesse a ser satisfeito. Recursos eram tanto os recursos vindos de outras autoridades, como freqüentemente os recursos de graça, pelo qual o Moderador revia as penas impostas aos condenados, para perdoá-las ou comutá-las.

Também são muito freqüentes, como se vê, as dúvidas vindas do Judiciário, de primeira ou segunda instância. Da mesma forma que as dúvidas vindas da Administração, as dúvidas vindas do Judiciário estavam diretamente relacionadas à aplicação da lei no caso concreto. E nessa tarefa era preciso que o Conselho decidisse ou bem se realmente se tratava de dúvida que pudesse decidir, ou se era o caso de remeter o assunto ao governo (para regulamento), para a Assembléia Geral (para legislação), ou se devolvia o assunto ao consulente tanto pela clareza do texto quanto pelo fato de a "inteligência da lei" no caso concreto pertencer propriamente ao Judiciário. Em diversos casos o Conselho devolveu a dúvida ao juiz ou tribunal repreendendo-o por não decidir e protelar a decisão sob pretexto de dúvida. Somadas as dúvidas vindas da Administração e do Judiciário, elas ocuparam, como foi dito, um terço da atividade da Seção de Justiça.

0 número excessivo de 'outros' inclui coisas muito diversas: estão aí incluidas as consultas feitas diretamente pelo Ministro da Justiça (ou em casos muito raros outro Ministro), pelo próprio Imperador (freqüentemente pedindo a opinião do Conselho sobre projetos de lei e regulamento), pequenos casos determinados (incidentes diplomáticos - visto que a seção também tratava de negócios estrangeiros, opiniões sobre a relação com a Santa Sé, etc), assim como representações de pessoas ou grupos. As representações eram muitas vezes queixas contra uma autoridade ou contra um particular (às vezes contra alguém contra quem já se litigava em juizo, por exemplo), e representações de grupos de interesse para que fosse mudada a legislação em algum ponto (por exemplo, os corretores e tradutores que pediam revisão de emolumentos ou a atualização de seus regimentos e decretos regulamentares e assim por diante, ou suas opiniões no caso da crise bancária de 1864 , etc.). Esses pedidos não eram, porém, petições para 
A seção por unanimidade rejeita a proposta paulista, fazendo uma longa análise dos males sociais da escravidão dando a entender que não haveria beneficio algum na sugestão vinda de São Paulo. Na sessão compareceram e votaram o Visconde de Abrantes, Paulino José Soares de Sousa e Caetano Maria Lopes Gama. 0 voto é de uma candura bastante impressionante, pois afirma com todas as letras que nos processos contra os escravos os meios de acusação e do acusado (o senhor) eram sempre superiores aos da defesa e do acusado. E o terror que se esperava impor aos escravos com a Lei de 10 de junho de 1835 provava-se pelas estatísticas da administração judiciária completamente ineficaz: "os crimes que por ela se quis evitar ou ao menos diminuir tem progressivamente avultado." a defesa de um direito ou interesse que estivesse ameaçado por alguma ação concreta de alguém, por isso não foram classificados como pedidos que a Administração pudesse de imediato deferir ou indeferir. Esse número alto de outros mostra bem que uma boa parte da atividade da Seção era também de aconselhamento puro e simples do governo ou do Ministro.

Com os dados recolhidos será possivel no futuro proceder sua análise qualitativa. Seria o caso então de confirmar-se a existência de orientações do Conselho, de manifestações de cultura jurídica e inclinações por escolas ou princípios jurídicos determinados, tanto no direito público quanto no direito privado. Existem já claras distinções ou inclinações de alguns dos personagens mais constantes nos debates da seção, como Maranguape e Jequitinhonha, por exemplo. Outro elemento a ser examinado encontrase nos pareceres dos consultores do ministério, entre os quais surgem os nomes de José de Alencar e Cândido Mendes de Almeida, para não falar dos advogados do Conselho, admitidos até 1880 (Decreto 2.993 abole o cargo de advogado do Conselho), como Teixeira de Freitas, Perdigão Malheiro e Saldanha Marinho. Tudo isto, porém, será o objeto da análise futura.

\subsection{As questões estruturais que ocuparam a Seção}

Destaco algumas questões estruturais para a sociedade brasileira e a constituição do Império que transitaram pelos pareceres da Seção de Justiça sem oferecer ainda uma interpretação mais sistemática. Ou seja, por meio dos casos pode-se mapear temas jurídicos recorrentes que remetem às estruturas sociais de poder.

\subsubsection{Escravidão}

Claro que a escravidão foi um tema abordado pelos conselheiros. Manifestou-se em diversos recursos de graça pedindo redução ou comutação de penas. Aparecia também em questões que a Lei Eusébio de Queirós havia transferido à competência do Conselho, ou seja, presas de embarcações traficantes. Muitas vezes apareceu na interpretação da lei de 10 de junho de 1835 sobre o homicídio de senhores por seus escravos. Em diversos desses casos, que não comportavam recurso, o Conselho opinava pela comutação da pena fazendo notar que no processo de primeira instância a pressa e o rigor da punição haviam feito os juizes abandonar as formas do processo, desrespeitar os direitos do réu, aceitar como prova plena a simples confissão e assim por diante. Também foi apreciada uma proposta da Assembléia Provincial de São Paulo (sessão de 30/10/1854) sugerindo o aumento das penas para os escravos, visto que a se manter o código criminal, os escravos preferiam as penas ao cativeiro e não temiam cometer delitos que, por causa da condenação, terminavam por livrá-los de seus senhores. ${ }^{32}$ Nos debates também se percebe, a partir da década de 1870 a interpretação mais favorável às leis relativas à escravidão, o que leva o Conselheiro Nabuco, por exemplo, a insistir que a lei Feijó, de 1831, não deveria ser aplicada a favor da liberdade dos escravos, pois não era esta a intenção original do legislador (sessão de 24/10/1874, com voto de Nabuco e Jaguary). Chama a atenção este posicionamento, em que menciona expressamente os malefícios da campanha abolicionista, pelo curioso fato de ser este um dos argumentos jurídicos encampados por seu filho Joaquim Nabuco alguns anos mais tarde no Abolicionismo.

A escravidão é o campo privilegiado, em que majoritariamente se invoca o direito romano no âmbito das consultas pesquisadas. E não sem 
Silêncio quanto às grandes definições do instituto escravidão, não silêncio total sobre pontos mais específicos. 0 que se nota é que o direito romano legitima uma instituição que fora dele já não achava respaldo. Lembremos de passagem que Teixeira de Freitas impugnou a constitucionalidade da entrada em vigor imediata da Lei do Ventre Livre com base no princípio do direito romano que estipulava a pertença do nascituro ao senhor da escrava já antes de seu nascimento, razão pela qual, aliás, a defesa de que o feto concebido constitui vida não disponivel para a mãe (escrava). razão. Quando a Constituição ou as leis nacionais não resolvem direta e expressamente problemas de acumulação de cargos, incompatibilidades e suspeições, uma das fontes que se invocam para o caso são as ordenações. 0 mesmo se nota em outros temas, nos quais em geral a fonte jurídica invocada é alguma ordenação contida na compilação filipina. A escravidão, no entanto, já não era reconhecida em nenhum ordenamento europeu moderno, ou seja, não era tratada com o detalhe que se encontrava no direito romano. Assim, dado o silêncio do direito pré-Independência, ${ }^{33}$ era o direito romano quem supria com elementos jurídicos o embasamento dos votos dos conselheiros.

\subsubsection{A política na justiça e a organização da burocracia}

Também em termos de grande estrutura social vê-se no Conselho de Estado o desfile permanente das rivalidades políticas locais. Pelo menos é esta a ótica com que os casos são apresentados por esses conselheiros em geral convictos dos benefícios da centralização. E de fato, não poucas vezes o que se tem são os horrores do localismo. Mas também se pode notar um confronto entre poderes locais e poderes centrais. Conflitos entre presidentes de província e juízes de direito envolvem, não poucas vezes a surda acusação de aliança de um ou outro com grupos locais que se apropriaram da Assembléia Provincial, ou que tumultuaram as eleições, ou que dominam certas comarcas de onde juizes são expulsos de fato pela violência de alguém. Algumas das consultas relatam com detalhe o histórico de tais conflitos e o Conselho vê com bastante clareza a distância que separa as "boas intenções" da lei e a incapacidade do governo e da justiça de fazerem-na chegar em toda parte. Diversas vezes exaltam a coragem heróica dos juizes, embora sempre se possa dizer que há um colorido especial nos relatos que talvez proceda da paleta de um centralista. De toda sorte, trata-se de decisões que poderão ser exploradas com vagar proximamente.

Outro ponto de grande interesse e que ocupa parte considerável da atividade da Seção de Justiça é a organização de uma burocracia judiciária. Uma grande dificuldade vem das discussões a respeito da natureza dos ofícios e empregos de justiça. Diversas vezes os juízes efetivos e vitalícios são chamados de juizes proprietários e o mesmo vale com mais razão para os servidores da justiça (oficiais, escrivães em geral, etc). Muitas vezes o que se vê é o jogo do interesse pelo cargo protegido pelas regras da propriedade dos rendimentos ou da expectativa de rendimentos, as obrigações de pagar as terças ou pensões aos serventuários anteriores e assim por diante.

São também bastante freqüentes as disputas em torno das suspeições e incompatibilidades no exercício das funções. Finalmente, destacam-se as muitas questões provenientes do número reduzido de gente capaz de servir (bacharéis, práticos e provisionados) nas comarcas e problemas vindos tanto da acumulação de funções (os ofícios anexados), dos conflitos entre provincias e governo geral nas divisões judiciárias (que afetavam os cargos anexos, as listas de promoção, etc), dos cargos de exercício temporário (juizes de paz, juizes municipais, jurados, escrivanias providas provisoriamente, etc), e da recusa de certos oficiais ou empregados de arcarem com novas incumbências (rejeição, por excessivamente trabalhosas e pouco rentáveis, de funções que se agregam a alguns ofícios, como o registro das hipotecas, por exemplo). Essa série de questões envolvem tanto problemas de política local, quanto indicam a dificuldade de se valer de ofícios particulares para exercer a autoridade pública no território. 
Uma idéia mais clara de burocracia e serviço público não está presente em muitos dos casos que subiram ao Conselho, coisa que também se reflete nos votos do mesmo Conselho que continua várias vezes a referir-se aos oficiais como 'proprietários' de seus ofícios. Visto que o Estado constitucional estava a converter-se em estado burocrático, a lentidão desse processo no Império fica patente nas atas. Um caso exemplar foi discutido na sessão de 14 de abril de 1858. Tratava-se de um recurso contra decisão do Ministro da Justiça a respeito do valor da terça a ser paga pelo novo serventuário da $3^{a}$. Vara Municipal da Corte. Segundo decisão do Ministro o cálculo deveria tomar por base o valor da lotação pelo qual o interessado havia finalmente obtido a escrivania a título vitalício. 0 recorrente pretendia que o valor fosse o anterior, pelo qual ele havia obtido provisoriamente o ofício. Uruguai e Eusébio de Queirós deram razão ao Ministro, mas Jequitinhonha votou a favor do recorrente. Na fundamentação de seu voto, diz o seguinte:

\footnotetext{
Nem pode servir de argumento a favor da opinião oposta o art. $1^{0}$ da Lei de 11 de outubro de 1827 [provimento de cargos e oficios de justiça e fazenda], que determina que nenhum ofício de justiça ou fazenda, seja qual for a sua qualidade ou denominação, será conferido a título de propriedade, porquanto fazendo-se a devida distinção entre o ofício e o seu rendimento, nenhuma dúvida há em entender e capacitar que se aquele não é propriedade, este o é no sentido mais rigoroso tendo a mesma natureza do exercício fixo e vitalício; e como tal, somente a lei o pode afetar com suas disposições.
}

Dois anos depois, voltava a aparecer a noção de propriedade para definir o estatuto jurídico dos cargos, embora o parecer penda finalmente a favor da Administração. Tratava-se então de uma correspondência vinda do juiz de órfãos da Corte que pedia a desanexação do ofício de escrivão de órfãos daquele de ausentes, com a sugestão de que a mesma pessoa os servisse para não Ihe diminuir os rendimentos. 0 parecer da Seção data de 30 de abril. 0 serventuário é chamado de proprietário pura e simplesmente, embora a Seção (por maioria: Eusébio de Queirós e Maranguape) digam que a sugestão do juiz só pode ser aceita por conveniência, já que contra o interesse público o proprietário do cargo não poderia opor-se à desanexação. A discussão do tema aparece em várias oportunidades e permanece sempre um objeto disputado o caráter de propriedade dos ofícios. Claro que a se equiparar o direito ao cargo com a propriedade, a noção de burocracia que daí surge pode ser bastante diferente da noção atual de cargo público.

\subsubsection{A autoridade última na interpretação e aplicação da leis}

Outro tema de permanente importância para a cultura jurídica e para a estrutura constitucional do Estado é a maneira de se compreender a interpretação da lei. Como já foi dito, o Conselho tem que decidir se a matéria que Ihe é apresentada pode ser ou não resolvida por ele. Há algumas possibilidades abertas, mas todas dependem de se compreender o que significa interpretar e o que significa aplicar a lei. Em geral, o Conselho trata a interpretação como uma competência exclusiva do poder legislativo, dando a entender claramente que o legislativo é quem aclara, ou declara as leis, podendo, pois, fazer leis interpretativas. A célebre Lei de Interpretação do Ato Adicional era apenas o exemplo mais conhecido de um desses casos. No século XIX discutia-se ainda qual seria o papel da doutrina na interpretação da lei, visto que desde o século XVIII o movimento de codificação e legislação caminhara no sentido de restringir o quanto possivel a doutrina 
(interpretatio) como fonte vinculante. Isto se encontra com bastante clareza nas consultas examinadas pois em diversas ocasiões o conselho confessa sua incompetência alegando que o assunto deve ser remetido à Assembléia para interpretação. Por outro lado, na maioria dos casos o Conselho emite sua opinião e não poucas vezes repreende os consulentes. Algumas delas contém mesmo verdadeiras lições a respeito do sistema de separação de poderes. Assim, na sessão de 22 de setembro de 1865, Pimenta Bueno reprova eloqüentemente o juiz de Itu, na sua província natal de São Paulo, por consultar desnecessariamente o governo:

\footnotetext{
Essa prática inadmissivel, de que não há exemplo em governo algum como o nosso, é oposta aos principios cardeais do sistema constitucional. 0 poder judicial, na aplicação das leis, é e deve ser inteligente e independente. Em sua inteligência, pois que sem ela não devem servir tais cargos, e em seu estudo devem os magistrados resolver as dúvidas que porventura tenham e em sua consciência aplicá-las independente de saber como pensa o governo. 0 contrário é colocar os direitos e as garantias do cidadão sob a tutela e assessoria do ministério, o que repugna à ordem constitucional. Por nossas leis fundamentais, essa fixação da inteligência das leis não pertence ao governo e sim ao Supremo Tribunal de Justiça. Este e só ele é quem estabelece a verdadeira doutrina a respeito da unidade ou uniformidade do direito e da jurisprudência, de sorte que a haver alguma fonte de tais esclarecimentos dever ser a daquele Tribunal. A prática abusiva que se segue pode e mesmo deve trazer o grave inconveniente de ser por ele rejeitada a inteligência dada pelo governo sempre que não estiver de acordo com ela. Algumas vezes aparecem dúvidas de alguns juízes tão destituidas de fundamentos que só servem para revelar pouca inteligência, que deveriam servir antes de motivo para censuras que para esclarecimentos, e entretanto eles demoram o expediente dos negócios.
}

A isto soma-se a própria prática do Conselho que raramente cita doutrinadores. É realmente excepcional que ele cite juristas, nacionais ou estrangeiros. Em geral o que se encontra nas consultas é um raciocinio fundado exclusivamente na lei e na constituição, com exploração dos fatos e das circunstâncias. Quando se invocam doutrinadores o que se vê é a citação de breves passagens que definem um ou outro instituto e em quase todos os casos os autores estrangeiros citados são franceses. Faz-se também alguma referência à experiência de legislação comparada, mostrando o conhecimento relativamente atualizado e vasto dos conseIheiros. De forma geral, porém, o que os votos expressam são concepções de princípio sobre os assuntos, bem como a clara idéia das injunções políticas e sociais na legislação brasileira. Trata-se, também aqui, de prática estimulada pela época. Tanto na Europa quanto nos Estados Unidos o constitucionalismo visava restringir a vida jurídica às fontes aprovadas, votadas e criadas pelos órgãos da representação política. Os tribunais superiores dos estados constitucionais eram às vezes proibidos mesmo de citar doutrina em nome da prevalência do direito (da lei promulgada pelos representantes do povo), de modo que os juizes (com a ressalva dos júris) fossem juizes de direito e não juizes de consciência.

Pode-se também analisar as consultas em função de um outro fator. Das dúvidas levantadas pelos juizes ou tribunais, $41 \%$ estão concentradas na área de direito penal (23 questões) e processo penal (cinqüenta e quatro questões). Será que os juizes consultavam quando tinham reais dúvidas ou a consulta serviria também para livrar-se dos casos penais mais espinhosos, por detrás dos quais se encontravam conflitos locais mais sérios? Tais conflitos envolveriam problemas de escravidão (como abusos de 
RODRIGUES, José Honório. Conselho de Estado: o quinto poder? Brasilia: Senado Federal, 1978. p.281.

35

CAPPELLETTI, Mauro. Juizes legis/adores? (trad. Carlos A. de Oliveira) Porto Alegre: Sérgio Antonio Fabris Ed, 1993. p.34. senhores sobre seus escravos, condenação de escravos sem recurso, etc.), ou mesmo conflitos locais de caráter político visto que desaguavam em questões de processo penal ou direito criminal mesmo a responsabilidade dos funcionários e, como se sabe, o uso do direito penal como arma contra inimigos políticos. Não se deve ignorar também que a consulta vinda dos juizes ou tribunais poderia indicar um desejo de agradar a Corte, decidindo mais conformemente à orientação do governo. Ou se pode bem pensar que o isolamento de alguns juizes, a falta de publicações de jurisprudência, a ausência mesmo da jurisprudência do Supremo, como já foi dito antes, as reformas parciais das leis sempre em andamento na Corte levassem honestamente os magistrados à incerteza.

\subsubsection{Estado e a modernização da infra-estrutura material}

Outra questão que cresce em freqüência e profundidade de debates é a dos contratos de concessão de serviços públicos. A partir da década de 1870 aparecem diversas e longas discussões sobre a forma de arbitramento das concessões de serviços de gás e de transporte ferroviário. 0 Conselho é nesta altura também um reflexo da modernização de infra-estrutura pela qual passa o Pais, e suas opiniões vão também numa direção mais liberal, várias vezes delegando ao Judiciário a solução da controvérsia.

Com tudo isto, pode-se sumariar muito do que se encontra nas atas da seção de justiça com a conclusão de que se tem ali um grupo realmente preocupado com a organização de um Estado de novo tipo. Debatem como sair do direito antigo (ainda vigente por força de muitos dispositivos das Ordenações Filipinas) e passar para o direito liberal; debatem também como sair de uma situação marcada originariamente pelo municipalismo, para o novo sistema legislado sob a idéia de representação. Nos atos da seção de justiça vê-se de forma particular como essas mudanças, que são estruturais no âmbito da política, da prática da administração social, do governo, mesmo do cotidiano das pessoas, sofrem idas e vindas e são elaboradas com a ajuda de um discurso jurídico organizador da realidade social. Esses homens são homens de estado, sem deixar de ser juristas e manifestam, com toda a ambigüidade que não pôde ainda ser explorada neste trabalho. Fica como advertência a opinão de José Honório Rodrigues: "Os conseIheiros eram sentinelas vitalícias da ordem, da segurança, da disciplina, pelo status quo, contra a mudança, contra as inovações." 34 No caso da seção de justiça, essa atitude não é fora de propósito. 0 juiz Devlin, mais alto magistrado da Inglaterra algumas décadas atrás, descrevia bem o que se pode esperar de juizes de direito: "Os juízes, como toda outra categoria de homens idosos, que tenham vivido vidas geralmente não aventurosas, tendem a ser tradicionalistas em suas idéias. Este é um fato natural." ${ }^{35} \mathrm{Na}$ seção de justiça o mais das vezes a solução, o conselho e o parecer oferecido ao Imperador é feito com razões jurídicas e não é descabido que seja, majoritariamente, um conselho moderado. Mas ao longo dos trabalhos, o que se deve ainda continuar a estudar, é que não poucas vezes a interferência do Conselho vai na linha da moderação justamente dos poderes locais, que precisavam, na sua perspectiva, de certa domesticação, tanto no trato dos escravos - como diversas vezes aparece na moderação das penas - quanto no trato da coisa pública e da burocracia que pretendia implatar. Suas queixas contra o quanto os "princípios constitucionais" ainda 
não haviam penetrado no Brasil é um sinal dessa espécie de moderação cujo objeto não é só a moderação sobre as massas, mas também sobre os poderes do Estado, locais ou centrais. Isto tudo, porém, virá com maior certeza à medida que se proceder ao estudo qualitativo mais aprofundado da documentação.

\section{Fontes impressas (Consultas da Seção de Justiça)}

Brasil. Câmara dos Deputados / Ministério das Relações Exteriores. (1981). Conselho de Estado 1842-1889: consultas da seção dos Negócios Estrangeiros. V. 3, Brasilia.

Brasil. Ministério da Justiça. (1907) Consultas do extincto Conselho de Estado sobre assumptos da competência do Ministério da Justiça e Negócios Interiores. Rio de Janeiro.

Brasil. (1869) Consultas do Conselho de Estado sobre negócios eclesiásticos. Rio de Janeiro: Imprensa Nacional.

Costa, Sérgio Correa. (1942) Pareceres do Conselho de Estado e do consultor do Ministério dos Negócios Estrangeiros (1842-1889). Rio de Janeiro: Imprensa Nacional.

Caroatá, José Próspero Jeová da Silva. (1884) Imperiaes resoluções tomadas sobre consultas da secção de justiça do Conselho de Estado, desde 1842 quando começou a funcionar até hoje. Rio de Janeiro; Garnier.

Mello, Bellarmino Braziliense Pessoa de. (1877) Imperiaes resoluções tomadas sobre consultas da seção de justiça do Conselho de Estado. Rio de Janeiro.

\section{Fontes manuscritas}

- Arquivo histórico do Itamarati

Livro de Atas - Seção de Estrangeiros - (342/1/12)

Livro de freqüência dos Membros do C. E. (1848-1857) - (342/3/20)

- Arquivo Nacional (Rio de Janeiro)

Cód. 296, Livro de assentamento do Ministros e Secretário de Estado e Conselheiros de Estado

Cód. 300, Sinopse e indice das consultas 1859-1870

Cod. 301, Livros de Atas (4 volumes)

Cod. 303 Livro de protocolo das consultas da seção de justiça (6 volumes)

Cód. 306 Consultas da Seção de Justiça resolvidas (48 volumes)

Cod. 969 (consulta sobre casamentos mistos e protestantes)

Cod. 1080 Livro do juramento dos advogados do Conselho de Estado

Recebido para publicação em fevereiro de 2007 